\title{
EL BISBAT DE GIRONA AL PRIMER TERÇ DEL SEGLE XV. APROXIMACIÓ AL CONTEXT SÒCIO-ECONÒMIC DE LA SĖRIE SÍSMICA OLOTINA (1427-1428)
}

ANTONI RIERA I MELIS

\section{SUMARI}

1. Introducció. - 2. Organització de l'espai. - 3. Població i poblament. -

4. El context sócio-cconomic. - 5. Conclusions. - Apèndix documental.

\section{INTRODUCCIÓ}

Aquest article és el tercer avenç parcial de resultats ' d'una línia de recerca que, amb la colaboració de Josep-Ramon Julià, Manuel Becerra, Josep Fernández Trabal, Sílvia Plana i Elisa Varela ', vaig emprendre el 1985 per tal d'analitzar la resposta -multiforme-oferta per la societat catalana dels segles XIV i XV a una modalitat de cataclisme: els terratrèmols. La finalitat d'aquest nou lliurement és força modesta: realitzar una aproximació al context dels sismes de la fase àlgida de la sèric olotina ' (1 427-1428), els més intensos de. tots aquells de què es guarda record al Principat. Durant acpuests dos anys, un seguit de fortes sotragades successives va causar destrossess a la dicicesi de

1 Els dos anteriors van ser: La societat catalana baixmediev'al datant els sismes. I: Els terratrèmols de 137.3, "Anuario de Estudios Medicvalles", 16 (Barcelona, 1986), pp. 251 306, i Fuentes y metodologia para el estudio de los seismos medievales en Cataluña, "Ibidem», 17 (1987), pp. 309-339.

2 Professors o ex-alumnes de doctorat del Departament d'Historia Medieval de la Universitat de Barcelona.

- Terme encuyat per Eduard FonTSERTi i Josep Icilisists a Recopilació de diades sismictues de les terres catalanes entre 1100 i 1906. Barcelona, Fundació Salvador Vives Casajuana, 1971, PP. 101-192. 
Girona i a les contrades veïnes, i va sembrar l'alarma en una àrea molt més àmplia: el vast triangle comprès entre Montpeller, Cahors i Tortosa.

Un terratrèmol, malgrat que sigui un fenòmen no desencadenat per l'home, es produeix, com qualsevol calamitat natural, en una àrea geogràfica concreta, on és assentada una col.lectivitat humana específica, el funcionament de la qual altera en major o menor grau. Per a poder mesurar sumàriament les seqüeles d'un sisme i la resposta oferta pels afectats és necessari conèixer prèviament el context demogràfic, econòmic, social, polític i cultural en què es va produir. Idees precises sobre la magnitud i la distribució del contingent humà a la zona trasbalsada, sobre l'ordenació de l'espai, la xarxa viària i el sistema urbà, sobre els materials i les tècniques constructives utilitzades en els diversos tipus d'immobles, sobre la jerarquització vigent al si de la societat, sobre els mecanismes de control polític i ideològic i sobre les pautes de pensament de cada col.lectiu social són de gran ajuda -si no imprescindiblesen el moment d'establir els trets definitoris d'un sisme pretèrit i copsar-ne amb precisió l'abast dels efectes.

\section{L'ORGANITZACIÓ DE L'ESPAI}

El bisbat de Girona, situat al nord-est de Catalunya és, com el limítrof d'Empúries, un dels creats durant el Baix Imperi Romà, el segle IV. Els seus titulars, durant l'època visigoda, assistiren regularment als concilis generals de Toledo i als provincials de la Tarraconense, un dels quals, el del 517, es va celebrar precisament a Girona ". La conquesta musulmana, entre el $711 \mathrm{i}$ el 720, hi va provocar, com en moltes ciutats hispanes, un tall brusc en el funcionament de la seu episcopal. El domini islàmic va ser, emperò, breu a les terres del nord del Llobregat: el 785, els notables de Girona, atrets pel model de societat vigent al nord dels Pirineus, desarmen la guarnició musulmana i lliuren la ciutat als francs. La incorporació de la plaça forta del Ter va significar la integració dels territoris situats al nord i al nord-est de la ciutat.

Les noves contrades frontereres van ser organitzades políticament en un conjunt de comtats i eclesiàsticament en una única diòcesi. El nou bisbat de Girona -el primer titular del qual fou el clergue franc Ataülf' - va incloure el

- Els cànons del qual han estat publicats per José VIVEs, Tomás Marín i Gonzalo MARTinez a Concilios visigóticos e bispano-romanos, Barcelona-Madrid, Consejo Superior de Investigaciones Cientificas, 1963, pp. 39-41.

' Que, el 788, figura ja entre els assistents al concili de Narbona [Ramón AlBERCHJosep Cl.ARA-Gabriel RoURE, El Gironès, "Gran Geografia Comarcal de Catalunya», 3, Barcelona, Fundació Enciclopedia Catalana, 1981, p. 62]. 
territori dels comtats de Girona, Besalú, Empúries i Peralada, ja que la vella seu de l'antiga colònia grega no va ser restaurada. Els seus límits precisos no els tenim documentats, tanmateix, fins el 1115; comprenien les comarques actuals dels dos Empordans, el Gironès, el Pla de l'Estany, la Selva (exceptuant el sector de les Guilleries i el terme de Riells), la Garrotxa (exclosos els termes de Falgar d'en Bas i de Joanetes), la vall de Camprodon (sense la Ral i Sant Pau de Seguries), al Ripollès, $\mathrm{i}$ el districte septentrional del Maresme (fins a Arenys de Mar) ". Aquests confins, que es mantindran inalterats fins al 1957, comprenen una extensió d'uns 4.900 quilòmetres quadrats, en la qual les contrades muntanyenques (els vessants meridional dels Pirineus i oriental de la Serralada Transversal i les capçaleres septentrionals de les serralades Pre-litoral i Litoral) coexisteixen amb les terres baixes (les planures de l'Empordà i del sector septentrional de la Depressió Prelitoral). El bisbat de Girona limitava, doncs, amb els d'Elna, al nord, de Vic, a l'oest, i de Barcelona, al sud, i amb el mar a l'est. Al final del segle XII, la diòcesi gironina es va estructurar en quatre ardiaconats: el major o de Girona, el de la Selva, al sud, el de Besalú, al nord-oest, i el d'Empúries, al nord- est '

A la Baixa Edat Mitjana, les circumscripcions eclesiàstiques i les administratives gairebé coincidien exactament: els territoris del bisbat de Girona corresponien als de les vegueries de Girona, Besalú i Camprodon ". La primera, més extensa que les altres dues, es va organitzar, el darrer quart del segle XIV, en tres districtes: la "part d'avall» (el Pla de l'Estany, el sector septentrional del Gironès i l'Alt Empordà), la "part d'amunt» (Rocacorba i les valls d'Hostoles i d'Amer) i les terres situades al sud del Ter (la Selva, la franja meridional del Gironès i el Baix Empordà) ". El funcionament del sistema feudal, pel fet de fragmentar el poder polític i distribuir-lo entre una àmplia jerarquia de vassalls reials que l'exerceixen en profit propi, superposa damunt cada vegueria una atapeïda xarxa de senyories, circumscripcions autònomes en què els sobirans

\section{"Ibidem.}

' Josep Maria PONS I GuRI, Nomenclàtors sinodals del bisbat de Girona al segle XIV. "Reculls d'estudis d'Història jurídica Catalana», II, Barcelona, Fundació Noguera, 1989, pp. 16-18.

" Maria-Mercè COSTA, Assaig cartogràfíc sobre la Catalunya de Jaume I, "X Congreso de Historia de la Corona de Aragón», II, Zaragoza, 1982, pp. 473-477.

"Aquesta divisió tripartida va ser proposada al rei, Marti l'Humà, el 1401, pels representants de les viles $i$ dels llocs que integraven la vegueria, amb una finalitat estrictament electoral, com a districtes per a designar els adjunts als procuradors que defensarien els seus respectius privilegis [Maria Teresa FERRER I MAL.LOL., El Patrimoni reial $i$ la recuperació dels senyorius jurisdiccionals en els estat.s catalano-aragonesos a la fi del segle XIV, "Anuario de Estudios Medievales», 7 (Barcelona, 1971), p. 428]. 
han anat renunciant, en favor d'un noble o d'una institució eclesiàstica, a l'exercici d'algunes funcions administratives ".

Les principals senyories laiques existents, cap el 1430, al bisbat de Girona eren: el comtat d'Empúries ", a l'Alt Empordà, empenyorat aleshores a la Generalitat de Catalunya i a la ciutat de Barcelona ${ }^{12}$, els vescomtats de Rocabertí ", també a l'Alt Empordà, de Cabrera ${ }^{14}$, a la Selva i al Maresme, i d'en Bas", a la Garrotxa, i la baronia de Cruilles-Peratallada ", al Baix

11) Com administrar justícia civil i, més rarament, criminal, recaptar impostos, nomenar oficials o agents de l'autoritat senyorial, mantenir l'ordre públic, atorgar cartes de poblament i exigir els serveis militars. Maria T. FERRER ha estudiat, en un extens i minuciós article $[E l$ Patrimoni reial, pp. 351-491], les jurisdiccions i els dret útils locals transferits, a canvi de préstecs, per la Corona a membres de l'aristocràcia i de l'alta clerecia, al llarg del tres-cents, arreu de Catalunya.

"El territori del qual s'extenia des dels Pirineus fins a la desembocadura del Ter, a Pals, i des del mar fins a una línia situada a l'est de les viles de Darnius, Figueres i Vilademuls, que ja queien fora de la jurisdicció dels comtes emporitans. El centre administratiu del comtat cra, des del final del segle XI. Castelló d'Empúries [Francisco MONSAI.va'T]E, Los condes de Ampurias vindicados, Olot, Ramón Bonct, 1917, pp. 9-10. Maria M. COSTA, Assaig cartogrc̀fic, pp. 474-475. Joan BAIIA, L'Alt Empordà. El Baix Empordà, "Gran Geografia Comarcal de Catalunyan, 4, 1981, pp. 16 i 53-54].

"Com a garantia d'uns préstecs concedits per aquestes dues institucions a la Corona [Cortes de los antiguos reinos de Aragón, Valencia y principado de Cataluña, VI, Madrid, Real Aciademia de la Historia, 1901, pp. 204-205. Arxiu de la Corona d'Aragó (en endevant AC.A), Cancelleria (en endevant C), reg. 2224, fols. 194 v.-197 r., i reg. 2225, fols. 7 r. -11 r. Institut Municipal d'Historia de Barcelona (en endevant IMHB), Llibre del Consell, 28, fols. 127 r.-v. Cit. Maria T. FrRRer, El Patrimoni reial, p. 358, notes 35 i 37].

1' Situat al nord del comtat d'Empúries, comprenia ambdós vessants de la serra de l'Albera: Cantillops, Darnius, les Escaules i Capmany, a l'Alt Empordà, i Maurellas i Bellaguarda, al Capcir. Dalmau IV, al darrer quart del segle XIII, va incorporar, per via matrimonial, la vila de Peralada, yue esclevinguci la capital del vescomtat [Maria M. COSTA. Assaig cartogräafic, pp. 474. Rocuberti, "Gran Enciclopedia Catalana», 2 ed., 19, Barcelona, 1988, p. 424].

1 El seu territori s'estenia des del litoral septentrional del Maresme fins al Collsacabra, comprenent una bona part del Montseny, de les Guilleries, de la Selva (fins a Anglès) i alguns termes de la Plana de Vic. Fil centre administratiu era Hostalric [Vicente COMA SOLFY, Los vizcondes de Cabrera, Barcelona, Librería Balmes, 1968, p. 19. Maria M. Costa, Assaig iartogräfic, p. 475. Ramon AlBerCH-Josep ClARA-Gabriel Roure, La Selva, "Gran Geografia Comarcal de Catalunyan, 3, 1981, pp. 207-208].

"Senyoriu centrat entorn de la vall alta del Fluvià, des d'on s'estenia per alguns territoris circundants; l'integraven les viles i parròquics de Sant Esteve y Sant Privat d'en Bas, Ridaura, Puigpardines, Sant Julià de Cabrera, Falgars d'en Bas, les Preses, Joanetes, Sant Joan dels Balbs, Rupit, Finestres i Castelló d'en Bas, que n'era el centre administratiu. Aqueste jurisdicció, inicialment patrimoni dels comtes de Besalú, va ser incorporada, el 1335, pel llinatge dels Cabrera [Francisco MONSAlvatje, El vizcondado de Bas, Olot, Juan Bonct, 1893, pp. 15-16. Maria M. CostA, Assaig cartogräfic, p. 476].

1" Que comprenia les viles de Cruilles, Peratallada, Canapost, Peralta, Begur, Esclanyà i 
Empordà. Entre les senyories eclesiàstiques sobresortien, per aquesta època, la de la mateixa mitra, que disposava de béns territorials al Gironès, als Empordans" i a la Garrotxa "18, la de la canònica de la seu, les dels monestirs benedictins de Sant Pere de Roda ", a l'Alt Empordà, de Sant Salvador de Breda ${ }^{20}$ i de Santa Maria d'Amer ${ }^{21}$, a la Selva, de Sant Feliu de Guíxols, al Baix Empordà, de Sant Daniel i de Sant Pere de Galligants, al Gironès, de Sant Pere de Camprodon "2, al Ripollès, de Sant Pere de Besalú ${ }^{23}$ i de Santa Maria de Ridaura, a la Garrotxa, i de Sant Esteve de Banyoles ", al Pla de l'Estany, i les del cenobis agustinians de Santa Maria de Vilabertran, a l'Alt Empordà, de Santa Maria d'Ullà, al Baix Empordà, de Santa Maria de Besalú, a la Garrotxa, i de Santa Maria de Roca-Rossa, al Maresme. Alguns monestirs importans ubicats fora de la diòcesi de Girona hi disposaven també d'enclavaments jurisdiccionals ${ }^{25}$. El funcionament de cada una d'aquestes institucions va

Regencós, entre les Gavarres i el mar. Els titulars de la baronia residien, descle mitjan segle XIII, a Peratallada [José Caruana, Los Cruilles y sus alianzas, Valencia, Ed. Diana, 1946, pp. 11 i 18. Maria M. CostA. Assaig cartogräfic, p. 475].

1. Entre els quals sobresortien les viles de Bàscara i de la Bisbal [Maria M. Cosra. Assaig cartogràfic, p. 475].

is La vila de Dosquers [Ibidem, p. 477].

1" Els seus dominis sobrepassaven els límits dels actuals Empordans, on només eren superats pels dels comtes d'Empúries, i s'estenien per les contrades veïnes [Joan BADIA, L'Empordì, p. 61]

211 Amb una àrea jurisdiccional integrada per Breda, Arbúcies, Buixalleu, Tordera, Blanes i per algunes altres localitats menors [Ramon AI.BFRCH-Josep CI.ARA-Gabriel ROURE, La Selva, p. 206].

$"$ El seu patrimoni s'estén per les valls del Brugent i del Ter, entre Amer, la Cellera i Anglès, i pel Baix Empordà, desde Colomers fins al mar [Esteban PrUENCA, El dominio territorial del monasterio de Santa Maria de Amer, tesi doctoral inèdita, Universitat de Barcelona, 1, pp. 51-52, 136 i 195-240).

22 Que disposava de terres a les capsaleres del Ter i del Fluvia, al Conflent, a la Cerdanya i al Vallespir [Antoni PI.ADreval.., El Ripollès, "Ciran Gieografia Comarcal de Caltalunya", 1 , 1981 , pp. 367-3681.

"La comunitat del qual posseïa terres a Besalú, Maià de Montcal, Fares, Juinyà, Porreres, Mieres, Ventajol, El Torn i Olot, a la Garrotxa, i a Tregurà, en els confins de la Cerdanya i del Ripolles Uosep Maria SAI.RACH, El comte-bishe Miró Bonfill i la fundació $i$ dotació de Sant Pere de Besalí (977-978), "Annals", 7 (Olot, 1989), pp. 14-31].

24 El domini del qual, no gaire extens, quedava gairebe circumscrit a Banyoles $i$ Porqueres [Maria M. Costa. Assaig cartogràfic, p. 477].

"Com el de Ripoll que, del 1097 ençà, disposava d'un important alou a la vall del Fluvià, integrat per la vila d'Olot, la més important de la Garrotxa, i per alguns territorris de la rodalia, des de Santa Andreu del Coll fins a Santa Maria de la Pinya [Ramón AlberchJosep Cl.ARÁ-Gabricl Roure, La Garrotxa, "Gran Geografia Comarcal de Catalunya", 3, p. $324]$. 
generar un gran volum de documentació, una part important de la qual s'ha perdut, com a consequèencia de la incúria o la cobdícia dels titulars, o ha estat incorporada, per matrimoni o herència, als arxius familiars de llinatges d'arreu de la Península Ibèrica ${ }^{26}$, uns àmbits sovint poc accessibles per als investigadors. Una bona part de la documentació de les abadies i dels priorats catalans, que sempre demostraren un gran interès per conservar el seu patrimoni escrit, es troba dipositada, des de la desamortizació del segle passat, a la secció de monacals dels arxius Histórico Nacional i de la Corona d'Aragó. La recerca de testimonis escrits relatius a l'activitat sísmica esdevinguda durant la Baixa Edat Mitjana al bisbat de Girona no pot quedar, doncs, circumscrita a la documentació reial i municipal: ha d'incloure també l'eclesiàstica i la nobiliària, encara que siguin força menys assequibles.

\section{POBLACIÓ I POBLAMENT}

Determinar el nombre i la distribució espacial de les persones assentades, en una data concreta de l'Edat Mitjana, en una regió del Principat no és, per manca de documentació adient, una tasca facil. Les úniques fonts que aporten informació quantitativa sobre la població catalana són d'índole fiscal: els fogatges, les talles i els estims. L'ascens ininterromput de les despeses públiques, com a consèqüencia de la intervencionista política exterior $\mathrm{i}$ interior de Pere el Cerimoniós, va provocar, des de mitjan segle XIV, un increment important de la pressió fiscal a Catalunya, en una època en què la regressió demogràfica, les migracions i la crisi agrària hi dificultaven tanmateix la recaptació dels impostos. Per tal de reduir l'evasió fiscal i distribuir la càrrega tributària entre el major nombre possible de contribuents, el sobirà, amb el consentiment de les Corts, va encarregar als oficials d'Hisenda la redacció dels primers fogatges ". Es tractava de mers recomptes puntuals de les llars solvents, ja que el monarca necessitava, per portar-los a terme, l'autorització de les Corts, en les sessions de les quals s'establia el nivell de riquesa de què havia de disposar una família per ser inclosa en el fogatjament. Ens han arribat quatre fogatges generals i nombrosos de fragmentaris. Els complets corresponen als anys 1359,

$\therefore$ La principal concentració de documentació nobiliària catalana es troba avui a Sevilla, a l'arxiu de la casa ducal de Medinaceli. Algunes famílies de l'aristrocràcia -amb un criteri molt lloable- han optat, en canvi, per dispositar els seus respectius patrimonis documentals en algun dels grans arxius del Principat, com el de la Corona d'Aragó, el Nacional de Catalunya o l'Institut Municipal d'Història de Barcelona.

"Joan Ferran Cabestany, La crisi demograffica dels segles XIV $i \mathrm{XV}$. "Historia de Catalunya», III, Barcelona, Ed. Salvat, 1978, pp. 169-171. 
1360-1370, 1378 i 1497; cap dels quals s'acosta, doncs, a la dècada que interessa, la de 1425-1435. El maneig d'aquests censos fiscals, les fonts amb més informació quantitativa sobre la població catalana medieval, suscita entre els experts en demografia històrica nombrosos recels: no inclouen les llars realment o fradulenta pobres, no especifiquen els integrants de cada família, són redactats $a m b$ criteris diversos ${ }^{28}$, amb les dificultats que això planteja a l'hora de confrontar les dades, i presenten força llacunes.

L'única via de què disposem per a evaluar la població del bisbat de Girona el trienni de 1427-1430, en la fase àlgida de la serie sísmica olotina, consisteix a adduir les dades del fogatge immediat, el del 1.378 , i intentar captar el sentit de l'evolució demogràfica en les cinc dècades que separen el primer terratrèmol destructiu de la redacció de l'esmentat cens fiscal. A l'etapa final de regnat de Pere el Cerimoniós, després de la contracció demogràfica provocada per les epidèmies de les dècades centrals del segle XIV, els funcionaris d'Hisenda evaluen les famílies fiscalment solvents de la diòcesi gironina en $15.991^{29}$ (el 20,5\% del total de Catalunya). Si tenim en compte que, entre 1378 i 1427, la crisi agrària i la tensió social varen coincidir, arreu del Principat, amb una relativa pau exterior i que la pesta només va aparèixer, a la vall del Ter, en dues ocasions ", podem considerar que el contingent humà no hi va experimentar entretant un canvi considerable i que devia superar, en produir-se el primer terratrèmol, els 11.783 focs registrats en el cens posterior, el de 1497 ", després que una llarga crisi econòmica, els deu anys de guerra civil, un seguit d'epidèmies successives " $\mathrm{i}$ alguns conflictes exteriors " delmessin la població catalana.

Com es distribuïa la població per les diverses contrades del bisbat? Es concentrava en les terres baixes: segons els càlculs de J. Iglésies ", el 77,6\% dels

2* Mentre yue uns s'estructuren d'acord amb les circumscripcions administratives, uns altres ho fan segons les demarcacions eclesiástiques. En ambdós casos, s’assignen sistemàticament a les grans senyories, els titulars de les quals aconstumen a pagar al fisc un tant alsat, el mateix nombre de focs, sense tenir en compte els canvis que hi ha experimentat, des de la redacció del fogatge anterior, el cont ingent huma Losep I(il.tsists. El poblament de Catalunya durant els segles XIV $i x V$, "VI Congreso de Historia de la Corona de Aragón», Madrid, 1959), pp. 247-27()].

2) Joscp IGitisits, El poblament de Catalunya, pp. 254-2551.

") Pel juny de 1410 i entre l'estiu del 1421 i la primavera de l'any segient [Ramon AlberCh-Narcís Castrall, La població de Girona, segles XIV-XX. Girona, Institut d'Estudis Gironins, 1985, p. 74].

$"$ Ibidem pp. 74-75.

12 Disset, en el cas de la ciutat de Girona [lbidem].

"Provocats per la conquesta de Nàpols (1436-1442) i per l'agressiva política exterior desenvolupada, a Itàlia i als Balcans, per Alfons el Magnànim en les decades centrals del segle $\mathrm{XV}$.

"El poblament de Catalunya, pp. 264-265. 
focs apareixen situats, el 1378, a altituds inferiors als $250 \mathrm{~m}$, a les planes litorals dels Empordans ", a les valls mitgeres del Ter i del Fluvià i dels seus respectius afluents $\mathrm{i}$ als voltants de l'estany de Banyoles. La situació, el 1427-1430, no devia ser gaire diferent. Les migracions des de les contrades muntanyenques cap a les planúries, força més adients per a l'agricultura cerealista extensiva que es practicava aleshores, va continuar durant tot el segle XV: els focs fiscals ubicats per davall dels $250 \mathrm{~m}$ signifiquen ja, el 1497, el $85,7 \%$ dels existents a la diòcesi. En aquest conjunt de planes aluvials es trobaven, si considerem que tres-cents focs conferien aleshores les característiques urbanes a un nucli de població ", les dues úniques ciutats del bisbat, Girona "i Castelló d'Empúries ", i gairebé la totalitat de les viles amb un contingent demogràfic superior a les cent llars: Torroella de Montgrí (243 focs "), Sant Feliu de Guíxols (230 focs "), La Bisbal (195 focs "), Palamós (170 focs $\left.{ }^{12}\right)$, Palafrugell (169 focs "), Figueres (154 focs "), Perelada (136 focs ") i Calonge (111 focs "). Només dos nuclis relativament importants apareixen ubicats per damunt de l'esmentada cota: Olot ${ }^{\text {"1 }}$ i Camprodon ${ }^{\text {th }}$. Els pobladors, a les terres baixes, tendien a concentrar-se en els pujols i els turons, formant nuclis aglevats d'uns 20 focs ". Els maresmes i els perills d'inundació

"Especialment a les terres de l'Alt Empordà, on el comtat d'Empúries, amb una densitat de població 10,36 focs per quilomètre quadrat, el 1.378, només cra superat, en tot Catalunya, pel Barcelonès, amb 53,65 focs per quilomètre quadrat Uosep IGLÉsies, El poblament de Catalunya, p. 262].

"Com proposa Josep Iglésies [El poblament de Catalunya, p. 270].

"Que comptava, el 1388, amb 1346 focs [Ramón AlberCh-Narcís Castril., La població de Girona, p. 311 .

" Que, el 1553, després de més de tres segles de retrocés demográfic, disposaval encara de 399) focs [Joan BaDia, l'Alt Empordia, p. 58].

"' El 1.497 [Joan BADIA, l. Alt Empordia, p. 66].

1" El 1360), i 258, el 1407 [lbidem].

" El 1497 [Ibidem, p. 64].

*. El 1497 [lbidem].

"El 1497 [Ibidem].

"El 1370 [Ibidem, p. 58].

.11 1.36 focs, cl 1370 [Ibidem, p. 60].

"El 1497 [Ibidem, p. 64].

"On la població va pasar de 230 focs, el 1378, a 279), el 1497 [Ramon Al.BERCH-Josep Ci.ARA-Gabricl Rolikl: La Garrotiat, pp. 314-315].

in Que comptava, cap cel 1370), amb 196 focs fiscals; les circumstancies adverses, durant la darrera fase de la Baixa Edat Mitjana, hi provocaran, como garirabé arreu de la Catalunya Vella, una important contracció demogràfica: la població solvent de la vila és avaluada, el 1553, en 81 focs [Antoni Pi.adeval.., El Ripollès, p. 366].

"Les viles amb un contingent humà oscil lant entre les 10 i les 30) llars solvents significaven, si s'accepten les xifres aportades per Joan BADIA [L'Fmpordia, pp. 58-62], el 
els obligaven a instal.lar-se als indrets més enlairats. A les contrades muntanyenques predominava, en canvi, el poblament dispers: la gent es repartia entre uns quants pobles, força allunyats entre si, i nombroses masies, organitzades en petites parròquies la feligresia de les quals rarament superava les deu famílies".

\section{EL CONTEXT SÒCIO-ECONÒMIC:}

La contracció demogràfica generada per la Pesta Negra va provocar, tant al camp com a les ciutats catalanes, una revalorització del treball humà, una alça espectacular dels jornals, que la Monarquia va intentar -infructuosamentcontenir ". Una bona part de les terres conreades amb mà d'obra assalariada es transformen, del 1.348 ençà, en àrees de pastura i, més tard, en boscos '". Les

44,4\% de les documentades, el 1378, a l'Alt Emporda i el 46,6\% de les taxades, cl 1497, al Baix Empordia.

"Com es desprèn de la informació aportada pel fogatge de 1.378 sobre la Vall de Bianya, a la Garrotxa; hi registra 68 focs fiscals, distribuits així: 13 a Santa Pere Espuig, 12 a Capsec, 11 a la Vall de Bianya, 10 a Sant Martí del Clot, 7 a Sant Adreu de Socarrats, 6 a Sant Andreu de Porreres, 4 a Sant Martí de Solamal, 2 a la Vall del Bac, 2 a Santa Maria Sacot i 1 a Vallcorba [Ramón Alberch1-Josep Ci.ARÁ-Gabriel Rourr, La Garrotxa, p. 366].

"Ramon d'ABADAl., Pere el Cerimoniós $i$ els inicis de la deciadencia política de Catalunya. Barcelona, Edicions 62, 1972, pp. 45-47. Francesc CARRI:RAs C.ANI) Idea del avenf urbà de Catalunya al segle XIV, "III Congreso de Historia de la Corona de Aragón», I, Valencia, 1923, p. 199. Antoni PI.ADF:VAI.I., La disminució de poblament de la Plana de Vic a mitjans del segle XIV, "Ausa", IV (Vic, 1963), p. 365.

"Com ho reflecteix clarament un document de la Plana de Vic, del 1351: *attendentes quod, propter mortalitates que fuerunt -permitente divino iudicio- in cititate Vicense et infra Ausoniam, anno Domini millesimo CCC (quadragesimo octato, honores et possessions terre non conreantur nec procurantur ut solebant ante tempus ipsatrum mortalitastum, pro magnis salariis et logueriis que dari habent agriculsoribus ac fossoribus, qui paluci remanserunt a tempore ipsarum mortalitatum citras [Arxiu Capitular de Vic, calaix 27, s.n.; cit. Antoni Pl.Al)l:val.1. Lat disminució de poblament de Vic. p. 366, nota 11. Pere el Cerimoniós, el 20) de novembre de 1380, autoritza la tala d'arbres en uns boscos rossellonesos que, per manca d'aprofitament, han esdevingut gairabe impenetrables per als ramats [José A. Garcia DI: CORTAZAAR. Nueves Historia de España en sus texto.s. Edad Media, Santiago de Compostcia, Id. Pico Sacro, 1975. pp. 592-593]; l'avenç de les pastures dintre de l'antiga àrea rompuda ha atenuat la preséncia del bestiar a les forestes. L'esclarida s'efectuarà en els boscatges cjue Jaume II de Mallorca va tancar, el 1306, per tal de protegir-los -en una conjuntura ben diferent-de les artigues i de la sobreexplotació ramadera [Archives Départementales des Pyrénćes Orientales, Llibre d'Ordinacions, I, fols. 36 r.-37 r.; ed. B.J. Al.ART, Documents sur la langue catalane des ancien.s comtés de Roussillon et de Cerdagne. Paris, Maisonncuve et Cic., 1881, pp. 164-1671. 
caresties bladeres "i les plagues de llagost ", dos malastres que reapareixeran sovint, durant els darrers centcinquanta anys de l'Edat Mitjana, al Principat, constitueixen algunes de les seqüeles més evidents d'aquest sobtat avenç dels erms a càrrec de les àrees rompudes, imputables també a l'encarcarament de les estructures agràries vigents aleshores arreu de Catalunya.

Moltes llars pageses perden, arran de la pesta, algun dels seus membres i els supervivents intenten refer la vida a les ciutats, atrets pels avantatges que aquestes oferien als immigrants". La deserció dels camperols repercuteix negativament en les rendes dels grans propietaris, que sol.liciten, a les Corts de

"En un moment en què el pa, com ho han demostrat Françoise DeSPORTES [Le pain au Moyen Age, Paris, Olivier Orban, 1987, pp. 103-209] i Louis STOUFF [Ravitaillement et alimentation en Provence aux XIV et XV siècles, Paris, Ed. Mouton, 1970, pp. 27-80], ha esdevingut el component primordial de la dieta ordinària d'àmplies capes de la població urbana i rural. Durant aquestes reiteratives crisis de subsistència, els cereals es converteixen en una mercaderia d'intensa circulació pels grans circuits del comerç internacional, aspecte estudiat per Marco TANGHERONI [Aspetti del commercio dei cereali nei Paesi della Corona d'Aragona. 1: La Sardegna, Cagliari, C.N.R., 1981], i els consells municipals de les grans ciutats han de posar a punt complicats mecanismes per tal d'assegurar-ne el proveïment als flecpuers i als particulars. D'acuesta actitud intervencionista de l'Administració local davant les caresties i les fams se n'han ocupat Claude CARRĖRE [Barcelona 1380-1462. Un centre económic en època de crisi, I, Barcelona, Ed. Curial, 1978, pp. 339-366], Mario DEL TREPPO [I mercanti catalani e l'espansione della Corona d'Aragona nel secolo XV, Napoli, l'Arte Tipografica, 1972, pp. X-XIV i 582-605] i Eva STRRA [Els cereals a la Barcelona del segle XIV, "Alimentació i societat a la Catalunya Medieval», Barcelona, Consell Superior d'Investigacions Científiques, 1988. pp. 71-108], per a Barcelona; Albert CURTO [La intervenció municipal en l'abastament del blat d'una ciutat catalana: Tortosa, segle XIV. Barcelona, Fundació Salvador Vives Casajuana, 1988], per a Tortosa; i Prim BERTRAN [L'assortiment de pa a Cardona, 1.379), "Cardener», 2 (Cardona, 1985), pp. 119-123], per a Cardona.

" "Die lane XVII die iulii, anno a Nativitate Domini M. CCC. L. septimo, et crastina die post sequenti, fuerunt celebrata festa in civitate Barchinone, et dicta lune ieiunavit populus, orando ad Dominum quod cessaret ipsum populum a tempestate locustarum que erant. ut dicebatur, in partibus Castelle et Valencie, et erant iam in partibus Dertuse et devorabant fructus et expleta terrarum» [Crònica del Racional de la ciutat de Barcelona (1334-1417), "Reculls de documents i estudis de l'Arxiu Municipal Històric de Barcelona», I-2 (Barcelona, 1921), p. 129]. Aquesta plaga ha estat comentada, de passada, per Pierre VII.AR [Catalunya dins l'Espanya moderna. Recerques sobre els fonaments econòmics de les estructures nacionals, II, Barcelona, Edicions 62, 1965, pp. 149-150], i per Àngels MASSIÀ DE ROS [Pere el Cerimoniós, Enric de Trastàmara $i$ l'entrada de tropes estrangeres a Catalunya, "Annals de l'Institut d'Estudis Gironins», XXV-1 (Girona, 1980)), p. 264]. Miquel Barceló ha estat el primer a insistir en l'estreta relació que pot existir entre les crisis agràries motivades per fortes contraccions demogràfiques i les plagues de Dociostaurus maroccanus, que devien utilizar les terres de conreus abandonades, encara toves, como a àrees de posta [Les plagues de llagost a la Carpetània, 578-649, "Estudis d'Història Agrària», 1 (Barcelona, 1978), pp. 67-84].

"Francesc Carreras CANDi, Idea del aven disminució de poblament a Vic, pp. 366-367. 
Perpinyà del 1350-1351, l'adopció de mesures per tal de posar fi al trasbals de població des de les terres de senyoria a les de reialenc, un trafegament en què participaven, aprofitant la confusió subsegüent a l'epidèmia, tant els pagesos no subjectes a redempció com els de remença ${ }^{\text {so. }}$. La iniciativa nobiliària va ser, tanmateix, neutralitzada pels braços burgès $i$ eclesiàstic, amb el pretext que era incompatible amb les constitucions generals del país. Els senyors, per tal de conservar la mà d'obra supervivent, es veren obligats, doncs, a fer concessions als conreadors, els quals van prendre consciència de la seva importància social. La mortaldat ha modificat la relació de força existent, durant l'etapa central de l'Edat Mitjana, al camp català i permet a alguns sectors de la pagesia exigir als terratinents una reducció de prestacions. La renúncia voluntària, per part dels conreadors, als predis poc fecunds, tot al.legant que l'explotació ja no resultava rendible ", sembla revelar que, aleshores, l'oferta de terra superava la de conreadors ${ }^{s}$.

Fins a mitjan segle XIV, el mas havia estat normalment una explotació familiar i una unitat de percepció de renda. Aquesta correlació jurídica es modifica ara, quan els senyors, mancats de camperols, es veuen obligats a autoritzar el conreu conjunt de diverses tinences per una mateixa família pagesa. L'agregació de masos va plantejar problemes a l'hora de recaptar els drets dominicals: el camperol, havia d'assumir les càrregues corresponents a cada explotació o només les específiques d'aquella que habitava? En els Costums de Girona s'estableix que la família que meni més d'un mas tan sols ha de pagar al senyor els drets personals corresponents a l'explotació principal ", el caput mansi o capmàs.

Els senyors diposaven d'altres solucions, com la de recuperar el domini útil

" Miquel GOLOBARDES, Els remences dins el quadre de la pagesia catalana, fins el segle XV, I, Figueres, Biblioteca Palau de Perelada, 1973, pp. 178-180.

"Els masovers especifiquen que les parcel.les retornades al senyor són inutilia et dampnosae magis quam profituosae [Miguel GOl.OBARDIS, Els remences, I, p. 18.3].

s* Les repercussions de la sobtada contracció demográfica en l'agricultura catalana de la segona meitat del segle XIV han estat estudiades, entre d'altres, per Eduardo de HINOJOSA [Origen y vicisitudes de la payesia de remensa en Cataluña, "Obras de Don Eduardo de Hinojosa", II, Madrid, Ministerio de Justicia-Consejo Superior de Investigaciones Científicas, 1955, pp. 12-13], Jaume VIClens Vivis [Historia de los Remensas (en el siglo XV), 2 ed. Barcelona, Ed. Vicens Vives, 1978, pp. 31-45], Ramon d'ABADAl. [Pere el Cerimoniós $i$ la decadencia de Catalunya, pp. 38-39 i 53-57], Pierre VIlar [Catalunya dins l'Espanya moderna, II, pp. 151-159], Miquel Gol.OBARDES [Els remences, 1, pp. 51-53], Eva SERRA [Pagesos y senyors a la Catalunya del segle XVII. Baronia de Sentmenat, 1590-1729, Barcelona, Ed. Crítica, 1988, pp. 25-39], Paul H. Frefdman [Assaig d'bistòria de la pagesia catalana (segles XI-XV), Barcelona, Edicions 62, 1988, pp. 49-59] i Josep Maria Sal.raCh [La Pesta Negra $i$ els orígens del problema remenf̧a. L'estat de la quiestió, «Pere el Cerimoniós i la seva època», Barcelona, Consell Superior d'Investigacions Cientifiques, 1989, pp. 13-34].

"Miquel Golobardes, Els remences, I, pp. 185-187. 
dels masos deshabitats ${ }^{60}$, per tal de restablir-los ${ }^{61}$. Aquesta sortida presentava, emperò, un inconvenient important: moltes famílies pageses no tenien cap interès per instal-lar-se, en les condicions tradicionals, a les explotacions abandonades -normalment les menys fertils de la contrada- $i$ exigien sovint dels propietaris, inclòs el rei, que, a més de declarar-les exemptes de tota mena de servituds, es conformessin amb la percepció d'un cens anual en metàl.lic i en espècie ${ }^{62}$. Els drets del senyor damunt el mas, arran del nou establiment, quedaven reduïts, doncs, al cens, al lluïsme, al foriscapi i a la fadiga, els propis d'una tinença emfitèutica, no servil ${ }^{63}$.

La millora de l'status dels camperols no va quedar circumscrita, tanmateix, als masos rònecs restablerts. En moltes explotacions que mai no.van ser abandonades, pagesos i senyors arriben a acords de redempció de prestacions servils a canvi de census certi, d'unes quantitats fixes en diners ${ }^{64} \mathrm{o}$, menys sovint, en cereals, un article de facil sortida en una època que el pa ha esdevingut el component bàsic de la dieta ordinària de les capes socials subalternes ". L'auge de les reduccions dels drets dominicals a pagaments

(1) Anomenats, a les fonts de l'èpocia, rònecs o caiguts ad benevisum.

(1) L'abat de Santa Maria d'Amer, ja el 1349, presenta, davant la Cúria de Girona, una declaració de masos rònecs, a fi d'oferir-los a noves famílies pageses [Francisco MONSAI.VATJE, Noticias Históricas, XII, Olot, Juan Bonet, pp. 446-448]. Deu anys després, fa un nou establiment del mas Lloret, a les Planes d'Hostoles [Josep Canal. Els remences a les Valls d'Hostoles $i$ d'Amer, "Revista de Girona», 118 (Girona, setembre-octubre de 1986), p. 53]. Els Rocabertí, senyors d'Hostoles, reclamen el domini útil, el 1359 , dels masos deshabitats de Colldoria, Coma i Mitjans, per al darrer dels quals, situat en el terme de Sant Feliu de Pallerols, trobaran un nou conreador el 1385 [lbidem].

(12) Pere el Cerimoniós, el 1362, per tal que Ramon de Limós es fes càrrec del mas Gasuac, del terme de Corsaví, al Rosselló, que romania deshabitat des de la Pesta Negra, el va haver de declarar exempt de tota mena de servituds, de toltas,... intestias, exorquias, cugucias et arsinas [ACA, C; reg. 913, fols. 30 r.-31 r.; cit Maria T. FERRFR, El Patrimoni reial, p. 430, nota 325]. Miquel Golobardes [E/s remences, I, pp. 187-188] aporta exemples semblants, relatius a senyors laics i eclesiàstics de la vegueria de Girona.

(1) Josep M. SALRACH, Els origens del problema remenf̧a, p. 29-30.

(4) Bernat de Montrodon, ardiaca de Besalú, el 13 de juny de 1349, redimeix Guillema, pagesa del mas Celrà, ubicat a Bordils, de tota mena de servituds i mals usos a canvi d'un cens anual de 12 sous barcelonesos [Arxiu Històric Municipal de Cornellà, Fons Bell-lloc, perg. 285; reges. Josep FERNÁNDEZ-Joan FERNÁNDEZ, Inventari dels pergamins dels fons Mercader-Bell-lloc de l'Arxiu Històric Municipal de Cornellà de Llobregat (s. XI-XVIII), I, Barcelona, Fundació Noguera, 1989, p. 193, n. 386]. Un quants mesos després, el 31 de desembre, Eimeric de la Via renuncia, a canvi d'un cens anual de 8 sous barcelonesos, a totes les servituds que pot exigir a Guillem de Bell-lloc, titular del domini útil del mas Gotmar [lbidem, perg. 289; reget. Ibidem, p. 194, n. 389]. Les reduccions de tasques a pagaments en metàl lic sovintegen en la documentació privada de l'època.

(1) Vegeu supra, p. 169, nota 52. 
periòdics en metàl.lic palesa l'articulació creixent de les economies senyorial i pagesa al mercat, als circuits comercials interiors del Principat.

La pagesia catalana, que havia experimentat una forta jerarquització interna, no constituïa, a mitjan segle XIV, un estament uniforme. Dos estudis recents sobre el patrimoni del capítol de la Seu de Girona "demostra que, el 1343, a les vigílies de la Pesta Negra, coexistien, al Baix Empordà, tres categories de camperols. La base de la piràmide l'ocupaven els pagesos menuts, més de la meitat dels capbrevats, les tinences dels quals, generades en gran part per subestabliments efectuats per altres terratgers $i$ amb una extensió inferior a les 7 ha, difícilment els devien assegurar l'autoabastament i alliberar-los d'anar a jornal. Per damunt d'ells es situaven els tinents intermedis, amb una incidència d'un $35 \%$ en el conjunt de la pagesia local, que disposaven de 10 a 20 ha de terra en usdefruit, suficients per a mantenir una família i, tal volta, per a contractar jornalers a les èpoques de més feina. El tercer esglaó corresponia als masovers grassos, una estreta franja -en cap comunitat no superaven el $1.3 \%$ dels censats- de titulars d'explotacions d'entre 20 i 40 ha de superfície, que disposaven ja d'excedents considerables, actuaven com a creditors dels camperols mancats de recursos i percebien rendes dels pagesos petits sots-establerts dintre la seva masada. Sembla evident que l'extensió de la tinença condicionava, aleshores, el nivell de vida de cada una de les famílies assentades en les nombroses senyories de la Catalunya Vella, però no n'era pas l'únic factor de jerarquització, n'hi havia d'altres, com la llibertat personal o la submissió a determinades prestacions senyorials només exigibles, per vexatòries, als serfs ". De les 112 explotacions capbrevades per la canònica de Girona a la Vall d'Aro, 45 (el $41,2 \%$ ), les més extenses, tenien al davant una família remença. Aquesta modalitat de pagesos disposava, en conjunt, del 65,4\% de la terra censada ${ }^{\text {"N. }}$. Les tinences no servils, majoritàries en nombre, no significaven, tanmateix, més d'un terç de la superfície reflectida en el capbreu.

Les repercussions de la crisi demografica damunt les diverses categorices de camperols no van ser uniformes sinó selectives. Els pagesos menuts, amb pocs estris i menys excedents, degueren ser el més efectats per la duresa dels

"ro Relatius a dues parròquies de la pabordia d'Aro, les de Santa Cristina i de Santa Maria de Fenals [Antoni Lluis SANZ, La pabordia d'A ro de la catedral de Girona, 1180-134.3, "Estudi General», 5-6 (Girona, 1985-86), pp. 419-436. Jaume PorTlilla-Antoni Ll. SANZ-Teresa BRUGADA, El cas de la Vall d'Aro (1486): un pacte de senyors enmig de pagesos miserables?, «Revista de Girona», 118 (Girona, setembre-octubre de 1986), pp. 44-49].

(1) Vegeu infra, pp. 175-176.

is Antoni Ll. Sanz, La pabordia d'Aro, pp. 427-428. Jaume Portel.la-Antoni Ll. SANz-Teresa Brugiada, El cas de la Vall d'Aro, p. 46. 
temps; la malaltia i la fam els van sostreure, llevat de rares excepcions, les energies necessàries per a ampliar les seves respectives explotacions, per a incorporar parcel.les abandonades. La solvència econòmica $i$ un utillage suficient van permetre, en canvi, als masovers benestants d'aprofitar la conjuntura per a permutar les terres mediocres per unes altres de millors i comprar a uns senyors desorientats per una sobtada contracció d'ingressos el domini útil de l'explotació que conreaven ", la llibertat personal " o la redempció de prestacions servils". La caiguda de la força de treball va contribuir, doncs, a accentuar les desigualtats entre els conreadors catalans, depauperant els petits i enriquint els grassos. Els masovers opulents, una minoria privilegiada que havia aconseguit millorar el seu status, coexistien, a les comunitats rurals, amb els camperols pobres, subjectes a la remença i a altres servituds personals i reals. Aquests darrers, aclaparats pels serveis i per les càrregues dominicals, reclamaven la disposició incondicional tant de les terres i dels béns mobles com de la seva persona, pugnaven per trencar una situació que consideraven oprobiosa i obtenir la llibertat "' sense perdre la tinença, aspiraven a determinar amb precisió - $\mathrm{i}$ al nivell més baix

(1) Transformant-se així en petits propictaris [Miquel Golobardes, Els remences, I, p. 193], en aloers, qui tenent fundos proprios cui a nemine cognoscunt nisi a Deo [Cosuetudines Catalonie, p. 170; cit. Esteban PrUenCA, El dominio de Santa Maria de Amer, II, nota 11 a, p. 485]. Degucren ser molts pocs, tanmateix, els pagesos que van disposar de solvència suficient per a poder escapolir-se del control econòmic senyorial $i$ assolir una autonomia completa.

"Passant d'home propi, soliu i afocat, adscrit al mas que conrea, a persona lliure i ingènua, amb el dret de traslladar-se quan i allà on vulgui, sense cap mena de restricció senyorial, i sotmès només a la jurisdicció reial. La compra de la pròpia llibertat o la dels fills va començar, entre els pagesos solvents, molt abans de la Pesta Negra: l'abat de Santa Maria d'Amer, el 1305, declara lliure, franca i immune Cília, filla de Bernat Jalbert, home propi del monestir, a canvi del pagament de 2 sous i 1 diner barcelonesos [ACA. Monacales, Santa Maria d'Amer, perg. 167; transcrit per Esteban PRUENCA. El dominio territorial de Santa Maria de Amer, IV, doc. 183, pp. 582-583]. Es, emperò, durant la segona meitat del segle XIV, quan aquesta mena d'acords esdevé freqüent, si més no al bisbat de Girona, on és objecte d'una detallada reglamentació: vegeu infra, p. nota 74 .

"Vegeu supra, pp. 172-173.

"Que és -com s'especifica en la carta de franquesa atorgada, el gener 1336, per l'abat Ferrer als habitants de la vila d'Amer- una aspiració natural de tots els homes, un tresor que no es pot comparar a cap més: acum bomines appetant naturaliter libertatem, que thesauro alicui non potest comparari, que a naturali iuri cuilibet est concessa. [ACA, Monacales, Santa Maria d'Amer, perg. 276; trans. Esteban PRUENCA, El dominio territorial de Santa Maria de Amer, IV, doc. 187, p. 599]. D'aquesta esperançadora declaració de principis, no en va derivar, emperio, cap millora per als pagesos que conreaven masos del monestir, ni tant sols per a aquells que habitaven la rodalia de l'esmentada població. 
possible- les prestacions que els senyors podien exigir per la renúncia al domini útil del mas i a esdevenir súbdits directes del rei. El programa de la pagesia ultrapassava, doncs, les meres reivindicacions econòmiques: inclö̈a una millora sensible de l'status dels tinents $i$, fins i tot, una redistribució del poder polític. Les modificacions que, arran de la Pesta Negra, es van introduir en les relacions contractuals que vinculaven els camperols solvents als senyors van contribuir a exacerbar el descontentament que ja hi havia entre les capes més baixes de la pagesia, entre aquells - molt nombrososque continuaven explotant les tinences en les oneroses condicions dels contractes primitius, concertats en un context econòmic i social molt distint al vigent després del 1350.

Els senyors no triguen gaire a superar la perplexitat en què els ha sumit el canvi de conjuntura i s'apressen a refer les seves rendes, a compensar amb noves exigències als pagesos menuts les concessions que acaben de fer als benestants. Malden per incrementar les prestacions econòmiques i el control dels camperols, per retrotreure els drets dominicals als nivells en què estaven abans del 1348. Els grans propietaris, a fi de tallar l'emigració en els seus respectius dominis, estenen el servatge" i eleven les quantitats exigides en concepte de redempció ". Mitjaçant procediments diversos, que van d'un ús "pervers» de

"1 Els pagesos de remença, una modalitat de camperols poc representativa abans del 1300, van experimentar una alça important durant la segona meitat del segle XIV [Paul $\mathrm{H}$. Freedman, Historia de la pagesia, pp. 49-53]: cap el 1400 significaven ja, amb més de 15.00() focs [ACA, C, reg. 1968, fol. 12 v.; Apèndix Documental, n." 3], prop d"una quarta part de la població total de Catalunya [Jaime Vicrens Vives, Historia de los Remensas len el siglo xV), 2 ed., Barcelona, Ed. Vicens Vives, 1978, pp. 18-19].

1 Que passen dels 5 sous barcelonesos, per als homes, i dels 2 sous, per a les dones, amb quie es conformava, cap el 1280, l'abat de Santa Maria d'Amer [AC.A, Monacales, Santa Maria de Amer, perg. 146; transcr. Esteban PRUENCA, El dominio territorial de Santa Maria de Amer, IV, doc. 137, p. 427] a la tercera part dels béns mobles que exigeixen, al començament del segle XV, els senyors, en el bisbat de Girona, als barons, a les pubilles i a les donzelles violades que volen esdevenir «lliures, francs $i$ immunes»; amb les verges casadores, una força de treball secundària en el mas nadiu i una peça clau en el procés de reproducció de la mà d'obra rural, els poderosos es mostren, en canvi, bastant més mesurats: els demanen 2 sous 8 diners, una quantitat assequible per a un ampli sector de les famílies pageses [Tomás de Mieres, Consuetudines diocesis Gerundensis, rub. 32, cap. 2, Usantiae civitatis Gerundae, rub. 27, cap. 1, i Apparatus super Constitutionibus curiarum generalium Cathaloniae, I, Barcelona, 1621, p. 51; cit. Listeban PRUENCA, El dominio territorial de Santa Maria de Amer. II, pp. 5()8-510)]. 
l'homenatge personal "fins a la violència física ", imposen als pagesos noves càrregues $\mathrm{i}$ amplien l'exigència dels mals usos, que, fusionats amb la remença ", esdeven ara les senyes d'identitat de la condició servil ${ }^{78}$. Per a refer títols i evitar l'erosió progressiva de la renda feudal, el bloc de poder disposava, a més, d'una eina adient, la capbrevació ", que utilitzarà, des de la Pesta Negra, amb una freqüència creixent, malgrat la resistència tenaç oposada pels pagesos ${ }^{\text {"0 }}$. La noblesa, alternant la violència institucional amb la física, neutralitza, al tercer quart del segle XIV, una bona part dels avantatges obtinguts, arran de la contracció demogràfica, per la mà d'obra rural ${ }^{\text {"1 }}$.

Els temps, tanmateix, també son difícils per als potentats, els quals, a mesura que la caiguda dels preus dels cereals i les devaluacions monetàries degraden les seves rendes, accentuen la pressió damunt la pagesia. Després

"La confusió interessada de l'homenatge personal amb les servituds va esdevenir, els anys centrals del segle XIV, un dels instruments utilitzats pels feudals per a coartar la llibertat de moviment dels camperols. Els habitants de Banyoles, per aquesta època, mantenen un llarg plet amb l'abat del monestir respecte a l'obligació de prestar-li homenatge. Els masovers justificaven la seva negativa en el fet que darrera d'aquesta exigència del senyor s'amagava el proposit de sotmetre'ls de bell nou als mals usos. La sentència de la cort reial, redactada el 1355, demostra que la sospita era justificada, ja que estableix que als vilatans han de prestar, en ser requerits, homenatge a l'abat, el qual, emperò, no podrà exigir-los ni la remença ni cap dels mals usos [Jaime Vicens VIVES, Historia de los remensas, p. 3.3].

"L'ús de la qual, contra els mateixos masovers, havia estat legalitzat per les Corts de Cervera de 1202 [Paul H. Freedman, Història de la pagesia catalana, pp. 107-129].

Durant les dècades centrals del segle XIV, aquestes dues exigències senyorials, inicialment ben diferenciades, es connecten i els pagesos sotmesos a una d'aquestes - com ho ha demostrat Paul H. FREFDMAN [Història de la pagesia catalana, pp. 49-50]- queden automàticament subjectes a l'altra.

"I són acceptades com a tals per l'Església: el concili provincial de Tarragona del 1.369, malgrat que molts de juristes coetanis haguessin insistit que no eren serfs ni esclaus, prohibeix l'ordenació dels pagesos de remença, acceptant i sancionant el raser-alt-en què els senyors han collocat la divisòria entre la llibertat i la servitud [Josep Maria PONS I GIIRI, Relació juridica de la remença i els mals usos a les terres gironines, "Revista de Girona», 118 (Girona, setembre-octubre de 1986), p. 40. Jaime VICENS VIVEs, Historia de los Remensas, [P. 34-35].

14) Algunes de les corresponents a terres de la diocesi de Girona han estat estudiades recentment per Antoni LI. SANZ [La pabordia d'Aro, pp. 425-436], Josep Maria RODRiguez [El caphreu d'Osor i de Susqueda, "Estudi General», I (Girona, 1981), pp. 109-112] i Josep Maria MARQuies [Vilobi d'Onyar a través del capbren d'en Ramon de Malars, "Estudis 1història Agrària", 5 (Barcelona, 1985), pp. 27-52].

"Nul Quc, si no disposaven de les escriptures de possessió del mas, podien ser obligats a concertar un nou conveni d'establiment i pagar el dret d'entrada estipulat pel senyor [Josep Maria Salrach, Els orígens del problema remença, p. 29].

"Paul H. Fritedman, Historia de la pagesia catalana, pp. $51-53$. 
d'esprémer els conreadors petits, els més vulnerables, orienten les seves exigències cap els tinents grassos, un col.lectiu que, aleshores, creia tenir a l'abast de la mà l'autonomia econòmica i la supressió de tota mena de servituds. L'ofensiva senyorial provoca una forta tensió entre els afectats, que explota en forma d'aixecaments locals aillats: a la primavera del 135.3, una massa de pagesos de Vic i la seva rodalia assalten la pabordia de Palau, el centre des del qual el monestir de Ripoll administrava les seves propietats d'Osona, i cremen tot quant hi troben, especialment les escriptures ${ }^{\text {*2 }}$. L'avenç del servatge, empès pels senyors i sancionat per l'Església ${ }^{\text {"', }}$, degué provocar, en les dècades següents, noves insurreccions rurals arreu de la Catalunya Vella.

La contestació camperola, durant el tercer quart del segle XIV, es transforma d'un moviment espontani i desvertebrat, en un autèntic front de resistència. Els camperols, vers el 1385 , s'han dotat d'organismes representatius, prenen decisions col.lectives i denuncien davant els juristes de la cort l'exigència arbitrària dels mals usos per part dels feudataris. El moviment, que arrencava de la convicció, compartida per alguns homes de lleis ${ }^{\text {n.-1 }}$, que els pagesos, inclosos els de remença, no són serfs i que, per tant, no poden ser sotmesos a les obligacions pròpies d'aquest estament, apunta cap al dret de la plena llibertat personal. La cohesió del bloc camperol -com veurem més endavant- es revelarà, emperò, fràgil, per tal com els interessos de cada estrat no eren idèntics. Tots rebutjaven els mals usos, la remença, el dret de maltractar i les taxes arbitràries; les coincidències, tanmateix, s'acabaven aquí, ja que, mentre els pagesos menuts " lluitaven per trencar i desmuntar el sistema feudal, els grossos només es batien per reinstal.lar-s'hi en millors condicions ${ }^{\text {"th }}$. Els senyors atiaran les contradiccions internes del bàndol contrari, que prolongaran el conflicte $\mathrm{i}$ li conferiran un caràcter confús $\mathrm{i}$ intermitent.

El nivell assolit per la tensió social al camp, l'afany d'afermar la seva autoritat devant dels senyors i la possibilitat de treure'n alguns subsidis econòmics inciten la Monarquia a acceptar una part de les reivindicacions

h2 Ramon d'Abadal., Pere el Cerimoniós i la decadencia de Catalunya, p. 56.

"' Que utilitza les condennes espirituals i, fins i tot, l'excomunió contra cls pagesos que es resisteixen a acceptar les noves exigències dels teudals Uaime VICins VIVIS, Historia de los Remensas, p. 34].

"I Com Jaume de Montjuic, comentarista dels Usatges [Paul H. FrFFDMAN, Histioria de la pagesia catalana, nota 24 a p. 158], o Tomàs de Micres [Apparatus super Constitutionibus Cathaloniae, II, pp. 513-514], ja en el segle XV.

" En el programa dels quals figuren, a més de la redempció dels mals usos i de les arbitrarietats senyorials, l'alliberament total de la terra i la negativa de pagar cap mena de censos ni de taxes als titulars del domini directe dels masos [Jaime VICENS VIVEs, Historia de los Remensas, p. 39].

* Josep M. SAI.RACH, Els origens del problema remenfa, p. 34. 
pageses. Joan I, el 13 de novembre de 1388 , suggereix a Climent VII la conveniència de permutar, en els dominis eclesiàstics del Principat, la intestia, l'eixorquia i la cugucia per un cens perpetu, la quantia del qual seria establerta mitjançant un arbitratge ${ }^{87}$. Uns quants dies després, persuadit pels representants dels remences que el «temps de la servitut és ja passat», ordena al batlle general de Catalunya que busqui a l'arxiu reial els testimonis documentals de l'abolició d'aquests tres mals usos i d' "altres drets» senyorials ${ }^{* 8}$, a fi de desautoritzar-ne la supervivència al nord del Llobregat. La doble iniciativa del monarca, que sembla no incloure la remença ${ }^{k "}$, no es tradueix, emperò, en cap resultat pràctic: la cúria d'Avinyó, en la fase àlgida del Cisma d'Occident, es desentén del problema i el comú dels senyors laics, insensible als plantejaments jurídic i econòmic del sobirà, es nega a redimir les servituds en els seus respectius dominis. La solució de la controvèrsia rural exigeix mesures força més enèrgiques $\mathrm{i}$ dissuasives que les ideades pels consellers de Joan I.

El descontentament popular, atiat per la intransigència senyorial, torna a esclatar el 1391, amb el saqueig dels principals calls jueus de Catalunya, un episodi d'una violència inusitada, protagonitzat pels «lumpen» d'intramurs i pels conreadors de la periferia urbana. La magnitud dels esdeveniments i la necessitat de finançar una campanya a Sardenya obliguen la Corona a tercerejar, de nou, en el conflicte: el gener de 1.395, Joan I proposa al tot just consagrat Benet XIII " una abrogació general, en els dominis eclesiàstics, de la cugucia, l'eixorquia, la intestia, l'àrsia i la remença, a canvi d'una idemnització de l'ordre de les deu lliures per llar i d'un cens permanent de quatre florins anuals, quantitats a repartir entre ambdós poders "'. La proposta del comte-rei, força més precisa que la que va formular, set anys abans, a Climent VII, era temptadora, ja que les famílies sotmeses als mals usos superaven, per aquestes dades, les $15.00(0)$. El sobirà podria consignar una part dels recursos obtinguts dels serfs eclesiàstics al rescat de les jurisdiccions alienades a la noblesa. La cúria avinyonesa, concentrada en la resolució de problemes més peremptoris, es decanta tanmateix pel sector més immobilista de l'episcopat català i torna a oferir el silenci per resposta. La receptivitat parcial de la Monarquia a les demandes dels camperols $i$ el seu -inoperant- desplegament diplomàtic no inciten precisament els senyors a la prudència: l'abat d'Amer porta a terme,

s' ACA, C, reg. 1955, fol. 103 v.; Apèndix Documental, n. 1.

r* AC, A, C, reg. 1955, fol. 105 r.-106 v.; Apèndix Documental, n. 2.

*.) Que no aparcix esmentada explícitament en cap dels dos documents.

\%) L.aragonìs Pere de I.luna.

$"$ ACA, C, reg. 1968, fol. 12 v.; Apéndix Documental, n. 3.

"Vegeu supra, p. 175, nota 73. 
entre 1397 i 1399, dues capbrevacions successives dels masos de què disposava la comunitat al Gironès i a la Selva".

La intervenció del sobirà en el problema remença obeïa a causes molt diverses ${ }^{14}$ : a la pressió creixent dels pagesos, a un afany de modificar la distribució del poder polític vigent a Catalunya i a les raons morals i jurídiques adduides pels juristes. Els comtes-reis, que aspiren a fer sentir la seva influència arreu del Principat i lliurar-se d'uns problemes de tresoreria cada cop més greus, aprofiten la revolta camperola per intentar refer la seva autoritat i el seu patrimoni a càrrec de la noblesa, per accelerar el procés de represa de les jurisdiccions territorials que havien hagut d'empenyorar o vendre en els moments de fortes dificultats econòmiques". Els camperols i el monarca, en els confins dels segles XIV i XV, compartien, per raons diverses, una mateixa actitud antisenyorial *. Aquesta concordança no va quedar circumscrita al terreny de la teoria jurídica, sinó que va condicionar també la pràctica política, com ho demostra el fet que la comissió creada, el novembre de 1400, per Martí l'Humà, per tal simplificar les redempcions jurisdiccionals al bisbat de Girona, estigués integrada pel mateix nombre de representats - dos-de la Corona, de l'Església local, del consell de la ciutat i de la pagesia ", composició sense paral.lel en els comitès creats aleshores en cada una de les restants circumscripcions administratives.

El projecte de redreç del Patrimoni reial avançava, per manca de canals de finançament, a un ritme molt pausat i no exempt de retrocessos "*. Martí l'Humà, incapaç d'activar el procés amb recursos propis, opta -reprenent una

"Josep Canal., Els remences a les Valls d'Hostoles i d'Amer, "Revista de Girona", 118 (Girona, setembre-octubre de 1986), pp. 52-53.

" Com ens ho ha recordat recentment Josep Maria SALRACH, Problema agrari i política de la monarquia en la crisi baixmedieval catalana, "Miscel-lània en homenatge al P. Agustí Altisent", Tarragona, Diputació Provincial, 1991, pp. 217-244.

"Una línia d'actuació ben estudiada per Maria Teresa lil:RRI:R, El Patrimoni reial, pp. 351-491. Segons aquesta autora, malgrat cue la transferencia de rendes i jurisdiccions reials a particulars adoptés normalment la forma d'una venda a carta de gracia, es tractava gairebe sempre d'un empenyorament, escripturat, per major garantia dels creditors reials, com un contracte de compra-venda; el preu estipulat en el conveni, en conseyüencia, responia, més que al valor objectiu del be cedit, a la quantia del préstec que el rei ja havia obtinguto esperava rebre del "comprador" [16idem, pp. 367-3681.

$\%$ Jaume Viciens Vivis, Historia de los Remensas, pp. 48-49.

"ACA, C, reg. 2296, fols. 109 r.-132 v.; cit. Maria T. Flikrie, lil Patrimoni reial, p. 380, nota 125. No sembla, tanmateix, que els camperols arribassin a elegir els seus representants, ja que posteriorment només es troben mencions de les «sis persones deputades a les redempcions de Girona" [ACA, C, reg. 2295, fols. 17.3 r. i 179 v.; cit. Ibidem, nota [26].

"Com ho demostren les alienacions efectuades, entre 1404 i 1409, pel sobirà arreu de la Corona d'Aragó [lbidem, pp. 356-358]. 
línia d'actuació temptejada durant el regnat del seu antecessor ${ }^{\text {"N }}$ - per traslladar-ne els costos damunt les viles afectades. El sobirà, el 1399, concerta un acord amb el consell municipal de Girona, en virtut del qual accepta de reintegrar al Patrimoni reial la jurisdicció d'onze localitats que la ciutat havia comprat dintre de la seva vegueria ${ }^{100}$ i la d'altres disset poblacions que, després d'haver-se redimit pel seu compte, s'havien lliurat a l'urbs del Ter. La transferència implica, com a contrapartida, que aquestes viles no podran ser segregades del reialenc: si el monarca o els seus successors tornen a alienar-les, la jurisdicció passarà, en franc alou, a la ciutat de Girona ${ }^{101}$. Un quants mesos després, pel novembre del 1400, Martí l'Humà subscriu unes noves capitulacions amb el consell i el capítol de la catedral de Girona, per tal de redimir la jurisdicció d'altres cinquanta-nou llocs del bisbat. Els pagesos ingressaran en una taula de canvi de la capital de la vegueria el preu de la redempció, calculat en uns catorze florins per foc. L'import global es distribuirà, en cada poble $o$ vilatge, entre totes les famílies camperoles, d'acord amb els seus respectius patrimonis. Per tal com moltes llars terrassanes no podran pagar la quota en efectiu, les autoritats locals són autoritzades a compensar-ne la manca de liquiditat mitjançant la venda de censals i violaris. Aquest procediment, segons els seus dissenyadors, permetrà el restabliment progressiu de la jurisdicció reial a la diòcesi de Girona "'1". Agents fiscals, per aquests anys, s'afanyen a endegar mecanismes de finançament semblants arreu de Catalunya '"'.' La lluüció, doncs, no correrà a càrrec del sobirà, sinó dels camperols sotmesos a la jurisdicció senyorial, a canvi d'algunes contrapartides reials, com el compromís

* Que ja havia arribat a un acord, el 1387, amb el consell de Girona per a activar les redempcions jurisdiccionals arreu de la vegueria. L'operació, tanmateix, no es va consumar, per manca de decisió dels representants de la burgesia gironina, alarmats pel volum de capital que exigia [ACA, C, reg. 2024, fols. 1 r.-5 v. i 18 r.-18 v.; cit. Maria T. FerRrer, El Patrimoni reial, p. 389, nota 167$]$.

101) Els representants de la burgesia gironina no dubtaven, doncs, a esmerçar recursos en el trencament del cinturó senyorial que s'havia anat formant entorn de la ciutat, en recuperar el control de la rodalia.

101 ACA, C, reg. 2296, fols. 12 r.-24 r.; cit. Maria T. FerRer, El Patrimoni reial, p. 391, nota 192.

110. ACA, C, reg. 2296, fols. 109 r.-132 v.; cit. Ibidem, p. 393, nota 194.

104 El rei nomena, en cada cap de vegueria, un comissari de les redempcions jurisdiccionals o més; els electes solen ser personalitats rellevants del lloc: juristes, ciutadans solvents i, fins i tot, membres de la petita noblesa. L'Administració central, per tal d'agilitzar la tasca dels esmentats promotors, destaca, a cada capital de circumscripció, un o dos jutges encarregats d'instruir i sentenciar les causes que sorgeixin entre el fisc i els detentors de béns patrimonials, $i$ un o dos advocats per defensar els interessos del monarca en els plets [Maria T. FERRFr, El Patrimoni reial, pp. 375-383]. 
de recuperar, mitjançant la consignació de rendes locals, les quantitats esmerçades ${ }^{104}$, les exempcions de contribucions reials ordinàries i extraòrdinaries ${ }^{101}$, la immunitat d'impostos comercials ${ }^{106}$ o la concessió del règim municipal a aquelles poblacions que encara no en disposaven ${ }^{107}$. Per tal com les negociacions es preveuen complexes, el sobirà, després d'exigir a tots els posseïdors de béns del Patrimoni reial que presentessin els títols ${ }^{110}$, autoritza els pagesos a reunir-se en assemblees i a integrar-se en sindicats ${ }^{110}$, , a fi de tractar amb els senyors i definir els mecanismes de recaptació de recursos, que solen anar des de l'establiment de talles "'" a la consignació d'una part de les collites "', passant per l'emissió de censals o violaris ${ }^{112}$ i la implantació de sises sobre els queviures ordinaris "1".

Aquesta iniciativa de la Monarquia va ser, en general, ben acollida pels aloers i pels pagesos grassos, cansats que els senyors els oferissin com a fiadors en les vendes de censals o els exigissin prestacions pecuniàries indegudes ${ }^{111}$. La

1004 La contribució econòmica de les poblacions a la pròpia redempció no va ser normalment a fons perdut: els representats de les viles van aconseguir incloure, en la majoria dels convenis concertats amb el rei, mecanismes de reintegració total o parcial dels capitals avençats. La Corona va consignar sovint a l'amortització de les bestretes la meitat dels ingressos generats per l'exercici de la jurisdicció recuperada i, en alguns casos, va renunciar, a més, a alguna altra renda, com el dret de barra [Maria T. FIERRIR, El Patrimoni reial, pp. $399-40()]$.

(11) Com toltes, forces, questies, cenes, do al rei, coronatge, maridatge, heretatge $\mathrm{i}$ redempció d'host i cavalcada [Ibidem, p. 40)(0).

twe Centenys i Cistella obtenen del sobirà, entre algunes altres concessions, no pagar lleudes ni barres en tots els dominis reials; Vinçà només hi aconsegueix immunitat de barres [lbidem, p. 426].

101' Com La Pera, Pedrinyà, Cassà de Pelràs, Centenys i Cistella [lbidem, p. 424].

I0* ACA, C, reg. 2295, fol. 169 v.; cit. Maria T. FE:RRER, El Patrimoni reial, p. 387, nota 161.

101) ACA, C, reg. 2295, fol. 14 r.; reg. 2296, fols 2 r. -2 v., 3 r. -3 v., 4 r. i 5 r.; reg. 2297 , fols. 3 r. -3 v. i 25 r.-25 v.; cit. Maria T. FI:RRl:R, lil Patrimoni reial, p. 408, nota 262.

111) La manca de licpuiditat d'àmplies capes de la pagesia obliga, tanmateix, els prohomes locals a emprar amb nolta precaució els impostos directes especifics; els reserven normalment per a completar les quantitats obtingudes mitjançant els altres procediments [Maria T. Ferrtir, El Patrimoni reial, p. 395].

'II Com delmes, redelmes, quints, vintens, tasques, agrers, etc. Aquest procediment, pel fet d'adaptar-se al ritme de les anyades, és el que s'ajusta millor a les conveniències dels petits nuclis rurals [Ibidem, p. 398].

11: Modalitats de credit a llarg termini que donen bons resultats als nuclis urbans i a les viles, que disposen d'unes finances prou fermes com per a poder pagar sense gaires dificultats la pensió anual [Ibidem].

"1" Que semblen suscitar menys recels, entre les poblacions afectades, que els impostos directes.

11' Ibidem, pp. 385-386. 
proposta va despertar, en canvi, més recels que entusiasme entre els remences menuts, per als quals el preu a pagar per una mera redempció dels drets jurisdiccionals era, pel fet de no implicar un relaxament efectiu dels principals vincles que els lligaven a la terra i al senyor " $"$," excessiu. La lluïció, amb les talles inicials $i$ les sises o els delmes escalonats en el temps, constituiia, en efecte, per a un ampli sector de la pagesia, una càrrega molt feixuga $\mathrm{i}$ amb una contrapartida reial insuficient. Moltes famílies camperoles, escasses de reserves, es neguen a contribuir econòmicament a la redempció jurisdiccional ${ }^{116} \mathrm{i}$ opten per concentrar els esforços i els recursos en la tasca -més urgent-d'eradicar la remença $i$ els mals usos. La resistència, un cop iniciats els tràmits, es polaritza entorn de la ferma, per un sector majoritari dels veïns, del sindicat que ha de negociar el reingrés del lloc en el reialenc, un estadi indefugible en el procés dissenyat pels assessors de Martí l'Humà "'. La coacció dels oficials reials, que no dubten a utilitzar la força contra els dissidents, desarbora la resistència en algunes viles " ${ }^{11 k}$. Allà on preponderen els pagesos pobres, tanmateix, les negociacions amb el senyor, després dels tempteigs inicials, s'empantaneguen per manca de decisió de les parts. El programa de redreçament del Patrimoni reial, pel fet de dividir els camperols en dos bàndols enfrontats, el dels partidaris de sortir de la jurisdicció dominical i el d'aquells qui maldaven per abolir les servituds reals i personals, genera una forta tensió social al bisbat de Girona, on els pagesos aprofiten la llibertat de reunió tot just otorgada per a tractar el problema

115 El reingrés en la jurisdicció reial -en contra del parer dels historiadors de l'anomenada "escola gironina» de la darreria del segle passat, des de Josep Pella i Forgas a Francesc Monsalvatje- no significava per als pagesos l'autonomia economica ni la llibertat personal, ja yuc continuaven sotmesos a les càrregues $i$ a les coaccions senyorials, des del cens a la remença, passant pels mals usos.

116. Una de les aportacions més innovadores -i ben documentades- de Maria T. FERRER al debat sobre la gènesi del conflicte agrari baixmedieval consisteix, precisament, a haver posar de manifest la fissura que les redempcions jurisdiccionals van provocar, al començament del segle XV, en la pagesia catalana [El Patrimoni reial, pp. 432-435 i 450)], un estament social aleshores ja força diversificat: vegeu supra, p. 173 ].

1" Segons el qual les assemblees populars, perquè les seves decisions poguessin ser portades a la pràctica, havien de delegar els seus poders en un o més síndics, que actuarien després en nom de tots els habitants de la localitat. El notari que donava fe d'aquesta delegació de facultats registrava el consentiment de cada vei. El sindicat es considerava constituit quan havia estat fermat per una majoria indiscutible dels habitants de la vila [Maria T. Ferker, El Patrimoni reial, pp. 408-410].

118 Com la d'Amer, on tres veïns, el gener de 1403, són obligats violentament pels agents reials, amb el consentiment exprés del sobirà, a ratificar el sindicat que ha de negociar amb el senyor el rescat de la jurisdicció, ja que els vint-i-quatre que l'havien fermat eren la "major e pus sana part» de la població local [ACA, C, reg. 2297, fols. 4 v.-6 r.; cit. Maria T. FisRlir, El Patrimoni reial, p. 414, nota 295]. 
-inajornable- de com transformar les seves respectives tinences de servils en emfitèutiques $\mathrm{i}$ assolir la llibertat de moviment. La Corona, davant l'ascens gradual del bàndol contestatari, decideix privar-lo de la seva principal plataforma d'actuació: el 25 de febrer de 1401, després de revocar tots els sindicats elegits a les darreres assemblees, prohibeix les reunions espontànies de camperols, en reserva la convocatòria als comissaris reials i hi restringeix la temàtica a debatre al rescat de la jurisdicció ${ }^{\prime \prime \prime}$.

El projecte de redreç del Patrimoni suscita un rebuig encara més ampli i intens entre els titulars de les jurisdiccions locals, poc predisposats a desprendre's, en una època de crisi, d'una important font d'ingressos i d'un eficaç ressort d'influència política. Els senyors, en detectar l'inici de les negociacions entre els pagesos i els delegats reials, desencadenen una persecució selectiva dels partidaris més decidits del canvi jurisdiccional: l'abat de Ripoll, des del 1399 , fustiga els prohomes d'Olot amb multes $i$, fins i tot, amb una acusació de bruixeria ${ }^{120}$, per tal de preservar el seu domini sobre la vila; per aquestes mateixes dades, els veïns de La Pera, Pedrinyà i Cassà de Pelràs i els de la Vall d'Hostoles són maltractats, per idèntic motiu, per Jaspert de Camplloc i per Guerau de Rocabertí, respectivament ${ }^{12}$. Els síndics han de sortejar pertot arreu, amb l'ajut -no sempre efectiu- dels comissaris regis, tota mena d'escomeses senyorials: exigències pecuniàries, penyores, intents d'agressió, demandes judicials etc. L'objectiu dels poderosos consistia a blocpuejar el procés, impedint que una àmplia majoria dels camperols fermés, com era preceptiu, el sindicat local. Els senyors procuren també neutralitzar l'actuació dels delegats reials, que no poden intimidar per la via de la violència física, mitjançant tota mena de subterfugis legals: presenten una allau de demandes davant els tribunals específics creats a cada capital de vegueria. L'abat de Ripoll considera il.legal la presa de possessió de la vila d'Olot pels comissaris regis i els denuncia, pel juliol de 1399, davant el tribunal episcopal de Girona, tot acusant-los d'apropiació indeguda de béns eclesiàstics ${ }^{12.2}$. La quantia de la redempció, calculada pels oficials del Patrimoni, constitueix normalment la causa que desencadena el contenciós: els titulars de les jurisdiccions de La Pera, Cassà de

111 ACA, C, reg. 2296, fols. 137 v.-138 r.; (it. Maria T. FERrlik, El Patrimoni reial, p. 427, nota 3211 .

1:11 El síndic Joan Sacoma, pel novembre de 1390, de retorn de la cort, on havia iniciat els tràmits de la lluïció, és inculpat d'haver-se introduït, arte dicabolica mediante, dins la casa de Jaume Calvó [ACA, C, reg. 2296, fols. 35 v. -36 r., 49 v. -53 r. i 58 r.-59) r.; cit. Maria T. FERRER, El Patrimoni reial, p. 441, nota 373].

121 Maria T. FerRer, El Patrimoni reial, p. 442.

122 ACA, C, reg. 2295, fols. 127 v. -128 r. i 161 r. -161 v.; reg. 2296, fols. 35 r. -36 v. i 81 v.-82 r.; cit. Maria T. FirRi:R, El Patrimoni reial, p. 437, nota 358. 
Pelràs i Pedrinyà, de Flaçà, de Sant Martí de Calonge i de la Vall d'Hostoles recorren el preu de la revenda ${ }^{123}$. Les diferències entre la Corona i els senyors sobre la magnitud de les lluïcions no va deturar, tanmateix, la marxa de les tranferències, ja que el sobirà disposava del recurs d'obrir un compte en una banca a favor del detentor de la jurisdicció, pel valor establert pels seus delegats, i reincorporar la senyoria per la força. El reingrés en el reialenc va quedar suspès, en canvi, en aquells llocs en què el titular va poder adduir impediments de naturalesa jurídica i no merament econòmica ${ }^{124}$. Alguns senyors van aconseguir, fins i tot, que la Corona sobresegués les redempcions endegades pels oficials del Patrimoni: al bisbat de Girona, Ramon de Xatmar, Guerau de Rocabertí, Berenguer de Palau i Berenguer de Cruilles, malgrat els acords concertats pels comissaris amb els pagesos, van assolir conservar la jurisdicció de Medinyà, la vall d'Hostoles, Vilanant i Sant Martí de Calonge, respectivament ${ }^{123}$.

L'intent reformista es va esgotar prest, com a conseqüència de l'obstrucció senyorial, de les dificultats exteriors, que van obligar la Monarquia, del 1408 ençà, a reincidir en les alienacions patrimonials per tal d'accelerar els preparatius d'una nova expedició a Sardenya, i de l'escàs suport ofert per un sector de la pagesia. La cancel.lació de la política de redreç del reialenc provoca un canvi de ritme en els contenciosos plantejats pels senyors contra les redempcions, els tribunals triguen cada cop més a redactar les sentències. Els diners de les lluïcions, reunits amb penes i treballs pels habitants de les senyories, romanen, sovint, immobilitzats en alguna taula de canvi o en les mateixes arques de la Corona, sense que les transferències de jurisdicció es portin a terme. Aquest és el cas de Peratallada i de Begur, a la baronia dels Cruïlles, o de Corçà i de Sant Sadurní de l'Heura, als dominis del bisbe de Girona. En altres indrets la situació és tan confusa que els senyors i els funcionaris reials s'atribueixen alhora la jurisdicció: a Olot i a Amer, durant les primeres dècades del segle XV, el jutge reial haurà de coexistir, no pas sense tensió, amb el de l'abat de Ripoll $\mathrm{i}$ el de la comunitat benedictina local, respectivament ${ }^{1: 6}$.

El procés de les redempcions jurisdiccionals va dividir la pagesia en dos bàndols enfrontats, va desencadenar la violència dels senyors i dels agents fiscals $i$, fins i tot, va provocar moviments migratoris en moltes viles en tràmit de lluïció. Malgrat tots aquests inconvenients - no gens menyspreables- els pagesos van obtenir alguns beneficis de la iniciativa del sobirà: van entrar en contacte amb els juristes i els comissaris reials, i la relació prolongada amb

12 Maria T. FERrer, El Patrimoni reial, pp. 438-439.

124 lbidem, p. 439.

12" Maria T. FERRFR, El Patrimuni reial, pp. 436-437.

12" Santiago SOBREQUÉs, La política remenga de la monarquia en temps d'Alfons el Magnisnim, "La guerra civil catalana del segle XV. Estudi sobre la crisi social i econòmica de la Baixa Edat Mitjana», Barcelona, Edicions 62, I, 1973, p. 14. 
aquests homes de dret els va permetre denunciar amb molta més exactitud la injustícia de la seva situació i els va mostrar el camí a seguir per deslliurar-se'n: la via de les assemblees $\mathrm{i}$ dels sindicats ${ }^{127}$. L'emancipació dels senyors era assolible per la via de la negociació, més lenta i menys exposada que la de la revolta oberta i l'enfrontament armat.

El 1402, mentre Martí l'Humà, amb el suport dels pagesos benestants, procurava recuperar jurisdiccions locals, la seva esposa María de Luna, en qualitat de lloctinent general de Catalunya, reprèn els contactes diplomàtics amb la cúria d'Avinyó, presidida encara per l'aragonès Benet XIII 1:8. Ben assessorada pels juristes de la cort, molt receptius, en aquesta època, a les reivindicacions dels diversos col.lectius camperols, sol.licita del pontífex, després de denunciar amb precisió i contundència les dures condicions de vida dels pagesos menuts al Principat ${ }^{129}$, que autoritzi el bisbe de Barcelona i l'abat de Santes Creus per a abolir, a canvi de censos perpetus, la cugucia, l'eixorquia, la intestia, l'àrsia, la remença i el dret de maltractar en els dominis eclesiàstics. De la redempció d'aquestes servituds, que no sostreu, segons els experts en la matèria, el masover del control senyorial ${ }^{131}$, en derivaran dos efectes força beneficiosos: un increment considerable de les rendes de la terra i una alça del prestigi del clericat, pel seu concurs en l'eradicació d'unes pràctiques inhumanes. La iniciativa de la lloctinència de Catalunya perseguia, una vegada més, que la jerarquia eclesiàstica, sota la pressió conjunta del papa i del comte-rei, acceptés la permuta de les càrregues servils per rendes en metàl.lic i mostrés el camí a seguir als grans propietaris laics. La resposta d'Avinyó, on es té una visió força precisa de l'abast del problema, no ultrapassa tanmateix el nivell de la mera evasiva: la modificació de l'estatut del pagès de remença s' ha de negociar amb els prelats de les diòcesis de Barcelona, Girona, Vic i Urgell, territoris on se'ls exigeixen sistemàticament els mals usos "'."

127 Jaume Vicins Vivis, Historia de los Remensas, pp. 39-40. Maria T. FrRrer, El Patrimoni reial, pp. 435-436.

128 ACA, C, reg. 2350 , fols. 43 r. -43 v., Apìndix Documental, n. 4.

129) Les més opressives i vils de totes les que es concixen al món, execrables, abominables i monstruoses, incompatibles tant amb les lleis divines $i$ humanes com amb la llibertat innata de les persones, un oprobi per a Catalunya $i$ un motiu d'escàndol per als estrangers [lbidem].

131) Ja que continua essent home propi i ha de continuar pagant el cens i les altres prestacions al seu dominans [lbidem].

131 ACA, C, reg. 2350, fol. 68 r.. Eds. Fidel FiTA, Benet XIII y los pagesos de remensa, doc. II-2, pp. 126-127; Francisco MonsalvatJe, Noticias Históricas, XIII, doc. 1740, pp. 172-173; Aurea L. Javierre, Maria de Luna, reina de Aragón, Madrid, Consejo Superior de Investigaciones Científicas, 1942, doc. 87, p. 255. El problema no devia afectar, doncs, els bisbats del sud del Llobregat (Tarragona, Lleida i Tortosa). 
La contesta de Benet XIII va decebre els jurisconsults de la cort i els dirigents del moviment camperol, per als quals era evident que la major part dels feudataris no estaven disposats a modificar les relacions socials al camp, a permetre que els pagesos de remença esdevinguessin, fins $i$ tot pagant, emfiteutes. A mitjan octubre, María de Luna, després de rebutjar, per retardatària i massa onerosa, en termes de prestigi, per a la Corona ${ }^{132}$, la proposta de la cúria, reformula al pontifex la seva sol.licitud inicial. La sobirana aprofita l'avinentesa per a exposar al seu parent que, en aquesta qüestió, no la mou l'afany d'avantatges econòmics, sinó el desig sincer d'eradicar injustícies, reduir la tensió social, incrementar les rendes del clericat i restaurar el prestigi internacional de Catalunya ${ }^{13}$. Li recorda que l'esmentat suggeriment és just i raonable, ja que confia la redempció dels mals usos al bisbe de Barcelona i a l'abat de Santes Creus, dos eclesiàstics d'una ferma formació jurídica i d'una gran experiència en el tracte amb els remences ${ }^{134}$. La requesta reial -exposada en un llenguatge d'una contundència poc freqüent en la correspondència diplomàtica de l'època- evidencia la inquietud que el contenciós rural suscitava, els primers

11: „Beatitudem vestram, quo humilius possumus, supplicamus... quatenus, derelictis via et practica tam longevis quas beatitudo vestra deirevit asservare, quibus, si tenderetur per eas, nullis accederetur temporibus ad conclusionem et finem per nos incepti negoci» [ACA, C, reg. 2350, fol. 67 r.. Ed. Fidel FiTA, Benet XIII y los pagesos de remensa, doc. II-2, p. 12.3]. "Car, jassia que la dita senyora entenga que los prelats e persones eclessiàstiques qui posseexen dels dits pagessos a la fi no porien contrastar als seus justos prechs; pero ajustar tants prelats, bisbes e abbats e priors e altres persones havents dignitats e beneficis, per concordar aquells al dit fet no. $s$ poria fer leugerament, sens grans treballs, afanys e messions e subjecció de grans prechs, qui seria de la dignitat reginaln [ACA, C, reg. 2350, fol. 68 v.. Ed. Fidel FiTA, Benet XIII y los pagesos de remensa, doc. 11-2, p. 127; Francisco Monsalvatjle, Noticias Históricas, XIII, doc. 1740, pp. 173-174; Aurea J. Javit:Rri, Maria de Luna, doc. 87, pp. 256-2571.

"'" "Que per esguart de pietat, gran profit e augmentament de les rendes de la Esgleya de Déu, e per foragitar e extrepar diverses inconvenients qui -s son seguits d'aquest fer c. $s$ poden seguir, per indegudes opressions que moltes de vegades són estades fetes a mà de les dites males servituts, de què-s són fetes nafres, morts, bandos e altres grans mals, la dita senyora vol, demana e suplica lo dit fet, sens neguna sinistra intenció d'haver-ne res, sinó solament mèrit de Nostre Senyor Déu e bona fama... per levar universal infamia a la nació catalana" [ACA, C, reg. 2350, fol. 68 r.. Eds. Fidel FITA, Benet XIII y los pagesos de remensa, p. 126; Francisco Monsalvatje, Noticias Históricas, p. 172; Aurea J. Javilirre, María de Luna, p. 255].

1" "La senyora reyna demana comissió ésser feta als dits prelats, qui han dels dits pageses e són prelats dotats de graus en sciència de canons e santa theologia,... prelats ecclesiàsthics sabents e entenents sciència de dret e de theologia, e qui posseexen e han dels dits pageses a les dites servituts obligats» [ACA, C, reg. 2350, fol. 68 r.. Eds. Fidel FiTA, Benet XIII y los pagesos de remensa, pp. 126-127; Francisco MONSAlvatJE, Noticias Históricas, XIII, pp. 172-173; Aurea J. JAvitirke, Maria de Luna, pp. 255-256]. 
anys del segle XV, a la Corona, que ja devia haver exigit ${ }^{145}$ als principals juristes i teòlegs catalans que sancionessin la seva acceptació parcial de les reivindicacions pageses. Ha arribat l'hora d'atendre, per tal d'evitar que la controvèrsia derivi en un conflicte armat, les reivindicacions de la plataforma unitària pagesa compatibles amb el sistema feudal. Per a restablir la convivència pacífica al camp, no basta, segons els assessors de la lloctinent, de fer avançar la jurisdicció reial, sinó que es necessari satisfer també alguna de les aspiracions compartides per tots els col.lectius camperols, inclosos els subalterns.

Benet XIII, en una situació molt delicada ${ }^{1 *}$, es nega, una altra volta, a tercerejar en el problema remença. La indecisió pontifícia bloqueja els projectes de la lloctinència del Principat. María de Luna, durant el bienni de 1403-1404, intensifica -infructuosament- la pressió sobre la cúria per tal que autoritzi la redempció dels mals usos -la principal aspiració dels pagesos menuts- en els dominis eclesiàstics de la Catalunya Vella ${ }^{137}$.

Mentre la inhibició pontíficia encoratja els senyors, molts dels quals, en comptes de renunciar a alguns dels mecanismes de control de la mà d'obra rural $^{138}$, continuen incrementant unilateralment les seves exigències als conrea-

1is Com es desprèn de les instruccions confiades per María de Luna a Jaume Ferrer, el seu representant a Avinyó: "la dita senyora reyna, per descàrrech de la sua consciència, havia ja fet disputar aquest fet a maestres de theologia e doctors solempnes, e trobat per justícia que tal e tan innominiosa servitut no és leguda de christià a christià, e molt menys és onesta c. no permessa a persones ecclesiàstiques» [ACA, C, reg. 2350), fol. 68 v.. Eds. Fidel FiTA, Benet XIII y los pagesos de remensa, pp. 127-128; Francisco Monsalvatje, Noticias Históricas, XIII, pp. 174-175; Aurea J. JANVIfrRf, Maria de Luna, p. 257].

146. França li ha retirat l'obediència i una bona part dels membres de la Cúria, després de desertar, s'han traslladat a Villeneuve, en territori gal. Gaudfred de Boucicaut, amb una host mercenària finançada pels cardenals rebels, s'ha apoderat de la ciutat d'Avinyó $\mathrm{i}$, des del 24 de setembre de 1398, assectja el pontífex, que resisteix al palau. La situació es mantindrà inalterada fins al 12 de mars de 1403, yuan una companyia catalano-aragonesal dirigida per Jaume de Prades, després de dues temptatives frustrades, allibera el papa, que s'instal la a Château-Renard, a la rodalia d'Arles [G. MOI.l.A'T, Episodes du siège du palais des papes an temps de Benoit XIII, "Revue d'Histoire Ecclésiastique», XXIII (Louvain, 1927), pp. 489)5011 .

1" ACA, C, reg. 2350, fol. 99 v.; ed. Fidel FITA, Benet XIIl y los pagesos de remensa, doc. II-4, pp. 127-128. ACA, C, reg. 2354, fols. 26 v.-27 r.; ed. Aurea J. JANVierri, María de Luna, doc. 98, pp. 269-270.

1* D'una eficàcia tanmateix limitada, com ho demostren les repetides fuites de pagesos: Pere de Bell-lloc, pel març de 1401, exigeix el retorn a una de les explotacions del terme del castell de Bell-lloc de Guillem Colomer, home propi, que s' ha instal lat de manera il · legal a Barcelona [Arxiu Històric Municipal de Cornellà de Llobregat, Fons Mercader, perg. 531; regt. Josep Firnández. Trabal., Inventari dels lions Mercader, I, n. 7()2, p. 336]. D'excmples com aquest en sovintegen en la documentació de l'època. 
dors ${ }^{139}$, les reiterades gestions de María de Luna davant la cúria refermen els pagesos en la defensa de les seves reivindicacions ${ }^{141}$. Aquest enduriment simultani de les respectives posicions incrementa la tensió social al Principat i crea una atmosfera propícia a l'esclat de la violència entre els dos bàndols enfrontats.

La intransigència d'un ampli sector del bloc feudal va obrir, al començament del segle $\mathrm{XV}$, un abisme insuperable al camp català i va reforçar l'ala més radical del moviment camperol. La tibantor entre senyors i pagesos degué assolir cotes sense paral - lel entre 1410 i 1412, arran del buit de poder creat per la mort sense successió de Martí l'Humà. Sembla que, frenades les transferències de jurisdicció i avortada la possibilitat d'una redempció global de les servituds '"', el destí dels masos rònecs va esdevenir aleshores l'element central de la controvèrsia. Els grans propietaris, alternant les vies legals amb l'ús de la força, procuren recuperar el domini útil de les explotacions incorporades en condicions molt favorables ${ }^{1.2}$, arran de la Pesta Negra, per nombroses famílies camperoles, a fi de restablir-les normalment en emfiteusi, a canvi de censos en metàl.lic amb un valor força superior al del conjunt de les prestacions que n'obtenien del conreadors. Els pagesos desproveïts projecten la seva agressivitat

119. El 1402, el mateix any de les esmentades gestions de María de Luna, Margarida, titular del mas Mersol, és obligada a reconèixer, pel paborde del monestir de Sant Cugat, que advenienti casu hauria de pagar eixorquia, intestia, cugucia i ferma d'espoli, malgrat que aquestes càrregues no figuressin en els documents anteriors [Jaume VICENS VIVES, Historia de los Remensas, p. 33]. D'arbitrarietats com aquesta se'n degueren donar també, aleshores, a les terres del bisbat de Girona.

1.11 Especialment aquells qui com Pere, fill d'Esteve Babiloni, de Sant Julià dels Torts, o Pere Sala, de San Pere Espuig, Joan Plambombart, Joan Soll i Pere Pujolar, de Sant Martí de Capsec, que s' han vist obligats, per conservar o ampliar el mas, a fer-se homes propis, solius i afocats dels monestirs de Sant Bartomeu de Bell-lloc i Sant Pere de Camprodon respectivament [Miquel Golobardis, E/s remenses, II, doc. 163, pp. 170-171. Francisco MOLSAl.VATJ1:, Noticias Históricas, XIII, rege. 1919, p. 401].

'1" No pas la de les individuals, especialment les de dones casadores i de fadristerns, la partença dels quals no comprometia l'explotació del mas: Guillem, abat de Sant Salvador de Breda, l'abril de 1400, redimeix de dona pròpia Francesca, filla de Guillem Monet Ballester, de la parròquia de Santa Maria de Pineda, pel preu de $38 \mathrm{~s} .6 \mathrm{~d}$. barcelonesos [Arxiu Històric Municipal de Calella, G-189; regt. Josep Maria PONS I Guri-Jesús Rodrígurz. Blanco, Inventari dels pergamins de l'Arxiu Històric Municipal de Calella (en endevant AHMC), Barcelona, Fundació Noguera, 1990, n. 295, p. 119); Guillem Ponç, fill de Bernat Ponş, home propi, soliu i afocat al mas Pons, del terme de Campins, compra, el setembre de 1409, la seva llibertat, per 2 florins, a l'abat de Montserrat [Arxiu Històric "Fidel Fita», P-16; regt. Josep Maria PONS I GURI, Inventari dels pergamins de l'Arxiu Històric "Fidel Fita" d'Arenys de Mar, Barcelona, Departament de Cultura de la Generalitat de Catalunya, 1984, n. 848, p. 234].

11. Vegeu supra, p. 171. 
contra el nous tinents, els senyors $\mathrm{i}$ els seus delegats, amenaçant-los de mort ${ }^{143} \mathrm{o}$ amb la destrucció de les collites. Amb aquesta iniciativa, el bloc feudal, a més d'acréixer les seves rendes, enfronta els camperols benestants amb els més pobres $\mathrm{i}$ aguditza les contradiccions internes en moltes llars pageses, tot incrementant la tensió -ja existent- entre el cap de família que mena més d'un mas i els fadristerns que volen establir-se pel seu compte, entre l'hereu i els cabalers.

La situació que hereta Ferran d'Antequera no és gens facil. L'alta aristocràcia aprofita el canvi de dinastia i les dificultats inicials del nou sobirà " per a arrencar-li, a les Corts de Barcelona de 1412-1413, un seguit de mesures contra la violència i la llibertat de reunió dels camperols ${ }^{1.13} \mathrm{i}$ el procés de sanejament de les finances reials. La rèplica dels pagesos - atiada per una carestia- no es féu esperar: van cremar collites i redoblaren les coaccions sobre els senyors i els conreadors que col.laboraven amb ells. Els Trastàmares -com els seus antecessors immediats de la casa de Barcelona- aspiraven tanmateix a refermar l'autoritat monàrquica a càrrec del bloc feudal. Ferran I, tot just desarticulada la revolta de Jaume d'Urgell, comença a desmarcar-se de l'alta aristocràcia i, a les Corts de Tortosa-Montblanc del 1413-1414, refusa ja totes les seves revindicacions ${ }^{1.46}$. El redreç de la conjuntura permet al seu successor, Alfons el Magnànim, passar a l'ofensiva. El braç nobiliari denuncia, a les Corts de Barcelona del 1416, que els camperols, assessorats per comissaris reials, tornen a organitzar-se en sindicats per tal d'escorcollar, malgrat els vets vigents, les vies de sortida de la jurisdicció senyorial. El monarca es nega a desautoritzar aquestes iniciatives, que repercuteixen favorablement en el seu patrimoni. Per aquesta mateixa època, un sector dels juristes reitera el seu suport al moviment remença sostenint que tot home és lliure i que, per tant, aspira a ser tractat com a tal ".'. L'entesa dels camperols amb la nova dinastia suscita descontentament entre els poderosos, que veuen alarmats com el sobirà, amb el concurs de llurs

11. Cavant fosses i aixecant creus en els camps transferits [Cortes de los antiguos reinos de Aragón y de Valencia y principado de Cataluña, XI, Madrid, Real Academia de la Historia, 19()7, p. 226].

1.1 La principal de les quals va ser la revolta de Jaume d'Urgell, el 1413, que va comptar amb el suport de la poderosa família aragonesa dels Luna.

14) Els masovers que, directament o per persona interposada, formulin amenaces contra els senyors, els seus representants o altres tinents, segons la constitució Com a molts [Cortes de Catalunya, XI, pp. 226-227], no podran beneficiar-se, mentre no reparin el dany que van causar $i$ complesquin la pena corresponent, de cap de les garanties establertes en els estatus de Pau i Treva.

146 Josep M. SALRACH, El problema agrari i la monarguia, p. 237.

147 Arxiu de la Seu de Manresa, Liber Praepositi, XV, fols. 257-289; cit. J. VICENs VIves, Historia de los Remensas, p. 39. 
pagesos, reinicia la recuperació de rendes i senyories. Alguns senyors passen de les queixes a l'acció i malmenen els veïns de les comunitats que intenten sortir de la seva jurisdicció ${ }^{118} \mathrm{i}$, en alguns casos, aconsegueixen, fins $\mathrm{i}$ tot, que tinents no adscrits a la terra ni sotmesos als mals usos ingressin en el servatge ${ }^{149}$. Els feudataris no constitueixen, emperò, un bloc monolític: els més innovadors i els menys solvents -dos sectors aleshores clarament minoritaris-accepten dels seus respectius pagesos considerables quantitats en metàl.lic en concepte de redempcions individuals de jurisdicció ${ }^{150}$ o de servituds ${ }^{131}$. Els efectes d'aquests canvis negociats d'status entre els camperols devien ser dobles: atenuar la tibantor social entre els beneficiats $i$ incrementar-la entre aquells que, per manca de recursos o per la intransigència del senyor, no hi tenien accés.

L'absència del Màgnànim, concentrat en la pacificació de Sardenya i de Sićlia i en la conquesta de Còrsega i de Nàpols, no provoca -d'entrada- un canvi de plantejaments en la política agrària de la Monarquia: la reina Maria de Castella, el 1420, després d'aprovar la lluïció de les set parròquies de la Vall

I is La reina Maria de Castella, en qualitat de procuradora general de Catalunya, ordena, cl 1419, a Joana, esposa de Ramon de Castellà, que cessi en les pressions que exerceix, com a represàlia per haver iniciat el procés de retorn a la jurisdicció reial, sobre els veïns de Pallerols, Sant Antolí, Timor i Sauer [ACA, C, reg. 2948, fol. 4; ed. Miquel Golobardes, Els remences, II, doc. 175, p. 185].

1w) Pere de Molleres, Joan Maiol, Guillem Marunys, Joan Colom i Pere Casadensac, masovers del patrimoni del monestir de Sant Joan les Fonts, reconeixen, el febrer de 1420, haver esdevingut homes propis del prior $i$ de la comunitat [Francisco MONSAI.VATJE, Noticias Históricas, XIII, regt. 1938, p. 410]; cinc anys després, pel febrer de 1423, ho fa Francesca, esposa de Bernat de Solar [lbidem, regt. 1938, p. 410].

111) Dalmau, vescomte de Rocaberrí, senyor de Cabrenys, renuncia , el març de 1412, a la jurisclicció de què disposava damunt Bernat Genís, de Maurellas, a canvi del pagament de 16 florins d'or d'Aragó [Arxiu Provincial de Girona (en endevant APG), Pere Pellicer, Manual 1412-1413, fol. 26; ed. Miquel Gol.OBARIDS, Els remences, 11, doc. 168, pp. 175-176]; un parcll de mesos després, pel maig d'aquell matcix any, Francesc Tomàs, de Vilancra, obté, mitjançant el pagament de $55 \mathrm{~s}$. melgoresos, de Garsenda, priora del monestir de Bell-lloc, el permis per a ingressar sota la jurisdicció reial [APG, Pere Pellicer, Manual 1412-1413, fol. 45; ed. Ibidem, doc. 171, p. 179].

1' L'abat de Sant Pere de Camprodon, el febrer de 1417, enfranqueix, a canvi del pagament de 10 florins, Mateu, de la parròquia de Sant Silvestre de Mor, i la seva filla Elisenda, homes propis de l'esmentat monestir [Francisco MONSAl.vatjE, Noticias Históricas, XIII, doc. 1743, p. 1771. Guillem, abat de Sant Salvador de Breda, el maig de 1417 , accepta de Margarida, filla de Guillem Monet Ballester, de Pineda, home propi del monestir, 8 florins en concepte de redempció de servituds [AHMC, G-246; regt. Josep M. PONS I GURI-Jesús RoDrígurz, Inventari de l'Arxiu de Calella, n. 363, p. 142]. Guillem Lografols i la seva esposa Francesca, homes propis del monestir de Santa Maria d'Amer, compren la seva llibertat a l'abat, per 6 florins [Francisco Monsalvat]F, Noticias Históricas, XIII, doc. 1744, p. 1771. 
d'Hostoles, autoritza els homes de Vilobí d'Onyar (la Selva), Pedrinyà, Caçà de Pelràs i la Pera (Baix Empordà) a reunir-se en assemblea a fi d'adunar els recursos necessaris per a redimir les respectives jurisdiccions ${ }^{152}$. L'agressiva política exterior d'Alfons $\mathrm{V}$, en la mesura en què desborda els ingressos ordinaris de la Hisenda, repercutirà, tanmateix, en el moviment camperol. La reina, per tal d'accelerar la tramesa de reforços a Itàlia, on l'ofensiva del Magnànim suscita una resistència creixent, ha de transigir, a les Corts de Tortosa-Barcelona de 1421-1423, davant dels braços nobiliari i eclesiàstic, que n'obtenen una renúncia expressa al nomenament de comissaris reials i a la represa de les senyories jurisdiccionals. El desassossec assoleix unes cotes tals que acaba per escindir el bloc oligàrquic en dues faccions: la radical, integrada pels feudataris que, com el bisbe de Girona, anteposen la defensa dels seus interessos a la fidelitat a la Monarquia, i la moderada, que agrupa els senyors que no volen portar aquesta disjuntiva fins a les últimes conseqüències ${ }^{154}$.

La contundent reacció dels poderosos, que els ha permès recuperar la iniciativa en el contenciós agrari, incrementa la tensió social al camp català. Nombroses famílies pageses, com a consequiència dels rescats de les jurisdiccions locals, de la pèrdua del control dels masos rònecs, de l'increment de les exigències senyorials $i$ de la sobrecàrrega fiscal, han sofert un empobriment important o han caigut en el servatge. De la documentació privada que ens ha arribat es desprèn que, el primer quart del segle XV, van ingressar en la servitud molts més camperols que no pas en van sortir. Cap el 1425, la major part dels tinents de l'Empordà, la Selva, el Gironès, les Guilleries i la Plana de Vic son remences, modalitat de pagesos que abunda també, encara que amb uns trets específics, al Vallès, al Maresme i, fins i tot, al Baix Llobregat "'.1. A la diòcesi de Girona, les condicions de vida dels camperols eren, aleshores, força més dures a les contrades muntanyenques que no pas a les terres planes "'. La situació va esdevenir especialment greu a la Vall d'Hostoles, on la població va experimentar, arran del reingrés en el reialenc " ${ }^{\prime \prime}$ d'un seguit de males collites $\mathrm{i}$ mortaldats, una forta caiguda "'. La manca de recursos no permetia als pagesos

132 Julián de CHIA, Bandos y bandoleros en Gerona, II, Girona, Paciano Torres, 1888, p. 64. Santiago SOBREQUIS, La politica remenfa d'Alfons el Masgnanim, p. 15.

19" Joscep M. Salrach, Problema agrari i monarquia, p. 2.38.

19. Jaume Vicins Vivis, Historia de los Remensas, p. 2()$.

iss Ibidem, pp. 20-21.

196. Vegeu supra.

15 Com es desprèn de la carta tramesa pels sobirà a Ferrer de Canyelles, ciutadà de Girona: «los de la dita vall, axí per mortedats com per sterilitas de lurs cullites e splets, són pervenguts a tanta inòpia, despopulació e destrucció de lurs persones e bens» [ACA, C, reg. 2789, fol. 20 v.]. 
pagar les pensions dels censals ${ }^{158} \mathrm{i}$ complir amb les càrregues dominicals $\mathrm{o}$ fiscals. Alfons el Magnànim, el 15 de febrer de 1427 -un mes abans de l'inici dels terratrèmols- pressiona els creditors perquè els concedesquin una moratòria ${ }^{13 \%}$. L'àrea epicentral, durant la tercera dècada del segle XV, travessava, doncs, una conjuntura adversa. Els sismes de la sèrie olotina, en la mesura que es cobraren vides humanes, posaren en fuita una part dels supervivents, malmeteren infrastructura i destruïren béns, van recruar, en algunes contrades de la Garrotxa i de la Selva, la contracció econòmica, la davallada demogràfica i la inestabilitat social. La trigança dels afectats a reconquerir la normalitat és imputable tant a la magnitud -inquestionable- de les destrosses com a la manca prèvia d'estalvis, de consens interestamental i d'una visió esperançada del propi futur.

\section{CONCLUSIONS}

El funcionament del sistema feudal va crear, al bisbat de Girona, durant els segles central de l'Edat Mitjana, una densa xarxa de senyories laiques i eclesiàstiques. La societat, entre 1050 i 1350 , va experimentar, a les contrades del nord-est de Catalunya, un llarg i ininterromput procés de jerarquització: molts dels terratinents esdevingueren poderosos feudataris, amb atribucions judicials i fiscals damunt de la mà d'obra instal.lada en les seves propietats, $i$ nombrosos aloers es van convertir en pagesos, en tinents subjectes als censos, a les prestacions $\mathrm{i}$ als serveis requerits pels titulars del domini directe de les terres que conreen. La gran propietat, abans de la Pesta Negra, va avançar a càrrec de la mitjana i de la petita, molt abundants durant l'Alta Edat Mitjana, com a conseqüència del protagonisme que havien assumit les capes rurals inferiors en el procés repoblador. La degradació gradual del vincle jurídic que uneix l'agricultor amb la terra redunda negativament en el seu rang: queda sotmès a la potestat del senyor, que li exigeix un conjunt creixent de prestacions, alguna de les quals més pròpia de la condició servil que de la d'home lliure, i no pot abandonar, sense l'autorització dominical, el mas ni transferir-ne l'usdefruit. La condició de pagès, amb totes les càrregues intrínseques, es transmet hereditàriament de pares a fills.

El procés de jerarquització social, a més de reduir molts petits propietaris a masovers i accentuar les barreres que els separaven dels senyors, va transformar

188 Amb què van finançar el rescat de la jurisdicció.

11\%) Ibidem. 
gradualment cada estament en un agregat de capes superposades. Els pagesos, a mitjan segle XIV, no constitueixen un col.lectiu homogeni; una desigual distribució dels recursos econòmics els ha escindit en tres categories força ben diferenciades: els menuts, els mitjans i els grassos.

La Pesta Negra trasbalsarà, el 1348, aquesta dinàmica social. Les seves repercussions damunt els diversos estaments no seran, tanmateix, uniformes sinó selectives. Encara que no disposem d'estudis detallats respecte d'aquesta qüestió, no sembla massa arriscat considerar que la resistència davant la malaltia degué dependre de les condicions de vida específiques de cada col.lectiu. Els efectes de la pestilència devien augmentar en funció dels dèficits alimentaris i dels dispendis energètics. Moltes famílies de la pagesia menuda sucumbeixen davant la duresa dels temps i es veuen obligades, després d'abandonar l'explotació, a refer la vida en uns altres indrets menys hostils. La mort i la deserció dels camperols erosionen les rendes ordinàries dels senyors $\mathrm{i}$ redueixen la seva influència política en el Principat. Els feudataris, per tal de conservar la mà d'obra supervivent, atenuen les seves exigències als tinents $i$ procuren atreure els desarrelats mitjançant la concessió de terres en bones condicions. Les llars masoveres benestants menys afectades per la mortaldat poden aprofitar, en la mesura que disposen de força de treball, d'utillatge i d'estalvis, la conjuntura per a expandir les seves respectives explotacions i rescatar prestacions servils. La sobtada contracció demogràfica del 1348 va contribuir, doncs, a accentuar les desigualtats entre els conreadors catalans, depauperant els menuts i enriquint els grassos. Les modificacions que, arran de la Pesta Negra, es van introduir en les relacions contractuals que vinculaven els masovers als senyors susciten, entre els camperols acomodats, el desig de traduir al terreny jurídic l'ascens que acaben d'assolir en el pla econòmic $\mathrm{i}$ esperonen, entre les capes baixes de la pagesia, l'afany de trencar un sistema que les condemna a la misèria.

Els senyors, superada la perplexitat en què els havia sumit el brusc canvi de conjuntura, intenten compensar amb noves exigències les concessions que van fer en la fase àlgida de la crisi. Es ara, en les dècades centrals del segle XIV, quan els mals usos es fusionen amb la remença i esdevenen les senyes d'identitat de la condició servil. La noblesa, alternant la violència institucional amb la física, erosiona els avantages assolits, arran de la contracció demogràfica, per la mà d'obra rural.

L'ofensiva senyorial provoca una forta tensió entre els afectats, que explota en forma d'aixecaments locals aillats. La contestació pagesa, durant el tercer quart del segle XIV, es transforma d'un moviment espontani i inorgànic en un front coordinat de resistència. La cohesió del bloc camperol, com a conseqüència de la disparitat d'interesos dels col-lectius integrants, es revelarà, tanmateix, força fràgil: mentre que els pagesos menuts lluiten per desmuntar el sistema feudal, els grassos només es baten per reinstal.lar-s'hi en millors condicions. 
L'ascens de la tensió social al camp i la necessitat d'afermar la seva autoritat davant dels feudataris inciten la Monarquia a intervenir en el conflicte. L'objectiu de la Corona, en aquesta primera fase, consistirà a convèncer els senyors, tot començant pels eclesiàstics, de la conveniència de permutar els mals usos per un cens perpetu. El sobirà, conscient de la resistència que oferiran els poderosos a la redempció de les servituds, busca un aliat de prestigi, amb una gran autoritat moral, la Santa Seu. La iniciativa dels assessors de Joan I arriba, tanmateix, tard i es tanca amb un fracàs: la qüestió pagesa reclama mesures més persuasives que els raonaments jurídics o els imperatius ètics.

L'acceptació d'alguna de les reivindicacions camperoles per part del monarca obeïa a causes molt diverses, entre les quals figurava el desig de modificar la distribució del poder polític vigent a Catalunya. El comte-rei podia utilitzar l'empenta dels pagesos per a refer la seva autoritat i el seu patrimoni, molt malmesos com a conseqüència de passades i de recents dificultats econòmiques, a càrrec de la noblesa. El sobirà, per tal de fer sentir la seva influència arreu del Principat i posar terme als problemes de tresoreria, ha de recuperar gradualment les rendes i les jurisdiccions que, sota la pressió de reiterats dèficits pressupostaris, va haver de vendre o empenyorar a particulars solvents.

El projecte de redreç del Patrimoni reial, fins aleshores, havia avançat, per manca de canals de finançament, a un ritme molt pausat. Martí l'Humà, incapaç d'activar el procés amb recursos propis, opta, cap el 1400, per traslladar-ne els costos damunt els afectats: el rescat de la jurisdicció local es distribuirà, en cada vila o lloc, entre totes les famílies, d'acord amb els seus patrimonis respectius. Els veïns podran recuperar, mitjançant consignacions de rendes locals o exempcions fiscals, les quantitats esmerçades en la lluïció. El sobirà, per tal d'agilitzar el funcionament del mecanisme, autoritza els pagesos a reunir-se en assemblees $i$ a organitzar-se en sindicats.

La iniciativa de la Corona, ben acollida pels petits propietaris rurals i pels masovers grassos, no va despertar gaire entusiasme entre els pagesos menuts, més interessats a deslliurar-se de la remença i dels mals usos que no pas a reingressar en la jurisdicció reial. On la mesura va suscitar una resposta més contundent va ser, com és lògic, entre els grans feudataris, poc predisposats a desprendre's, en un temps de crisi, d'una important font d'ingressos i d'un eficaç ressort d'influència política. El procés de les redempcions jurisdiccionals, pel fet d'afegir a la violència senyorial la dels comissaris reials, va incrementar considerablement la tensió social al camp. Del mecanisme ideat pels assessors de Martí l'Humà en van derivar, per als pagesos, molts d'inconvenients i alguns pocs beneficis: el contacte continuat amb els juristes de la cort els va permetre analitzar amb més exactitud la seva situació i albirar noves vies de sortida.

Mentre Martí l'Humà, amb el suport dels pagesos benestants, procurava 
refer la seva autoritat i el Patrimoni reial a càrrec de la noblesa, la seva esposa María de Luna, en qualitat de lloctinent general de Catalunya, reprèn, el 1402, els contactes diplomàtics amb la cúria d'Avinyó. Ben assessorada pels juristes de la cort, sol-licita del seu parent Benet XIII que faculti el bisbe de Barcelona i l'abat de Santes Creus per a abolir, a canvi de censos perpetus, els mals usos als dominis eclesiàstics, una reivindicació compartida per tots els col.lectius camperols, especialment pels subalterns. Les dues iniciatives antisenyorials de la Corona fracassaran, tanmateix, simultàniament, com a conseqüència de l'obstrucionisme sistemàtic del bloc feudal, de les dificultats exteriors, que obligaran la Monarquia a reprendre, el 1408, les alienacions patrimonials, de la negativa del pontífex avinyonès, en una situació molt precària, a sancionar moralment les demandes pageses, i de la discordança dels mateixos tinents a l'hora de jerarquitzar les reivindicacions que integraven la plataforma comuna.

La intransigència d'un ampli sector del bloc feudal reforça, la primera dècada del segle XV, l'ala més radical del moviment camperol i obre una fractura cada cop més ampla en la societat catalana. La tibantor entre senyors i pagesos degué assolir cotes sense paral.lel entre 1410 i 1412, com a conseqüència del buit de poder creat per la mort sense successió de Martí l'Humà. Bloquejades les transferències de jurisdiccions locals i avortada la possibilitat d'una redempció global de les servituds, el destí dels masos rònecs esdevè ara l'eix de la controvèrsia. Els senyors, utilitzant procediments diversos, van recuperant el domini útil de les explotacions incorporades, arran de la Pesta Negra, per nombroses famílies camperoles, per tal de restablir-les en emfiteusi. Els pagesos desproveïts projecten la seva agressivitat contra els nous tinents, els senyors $\mathrm{i}$ els seus delegats. Amb aquesta iniciativa, els feudataris, a més d'incrementar les seves rendes, enfronten els camperols grassos amb els menuts i aguditzen les contradiccions internes en moltes llars pageses, elevant la tensió -ja existent- entre l'hereu i els cabalers.

L'alta aristocràcia aprofita el canvi de dinastia i les dificultats inicials de Ferran d'Antequera per a arrencar-li un seguit de mesures contra la llibertat de reunió dels camperols i el procés de sanejament de les finances reials. Els Trastàmares, tanmateix, aspiraven també a refermar, amb el suport dels estaments baixos $\mathrm{i}$ intermedis rurals $\mathrm{i}$ urbans, l'autoritat del sobirà a càrrec de la noblesa. L'evolució positiva de la conjuntura permet a Alfons el Magnànim reprendre, el 1416, la política antisenyorial dels seus antecessors immediats de la casa de Barcelona. El monarca reinicia, amb el suport d'un ampli sector dels camperols, que tornen a reunir-se en assemblees i a designar síndics, el procés de recuperació de rendes i senyories.

L'agressiva política exterior desenvolupada per Alfons $V$, en la mesura en què desborda els ingressos ordinaris de la Hisenda, repercutirà, tanmateix, en el conflicte agrari. La reina María, per tal d'accelerar la tramesa de reforços a 
Itàlia, on l'ofensiva del Magnànim suscita una resistència creixent, ha de transigir, el 1421, davant del bloc oligàrquic i renunciar a la represa de les senyories jurisdiccionals.

La recuperació de la iniciativa per part dels feudataris incrementa la tibantor social al camp català. Nombroses famílies rurals, com a conseqüència dels rescats de les jurisdiccions, de la pèrdua de control dels masos rònecs, de l'increment de les exigències senyorials i de la sobrecàrrega fiscal, han sofert, durant el primer quart del segle $\mathrm{XV}$, un empobriment important o han caigut en el servatge. Cap el 1425, la major part dels pagesoss de les diverses contrades del bisbat de Girona són remences. La degradació de les condicions de vida dels camperols és força més àmplia $\mathrm{i}$ intensa a les àrees de muntanya que no pas a les terres planes. La situació ha esdevingut especialment greu a la Vall d'Hostoles, on el restabliment de la jurisdicció reial ha anat acompanyat d'una forta caiguda de la població. La zona epicentral, en vigílies dels sismes, travessava, doncs, una conjuntura adversa. Els terratrèmols del 1427-1428, els més destructius de tots els sobrevinguts a Catalunya, van recruar, a la Garrotxa i a la Selva, la contracció econòmica, la davallada demogràfica i la inestabilitat social. La trigança dels afectats a reconquerir la normalitat és imputable tant a la magnitud de les destroses com a la manca prèvia d'estalvi, de consens interestamental i d'una visió esperançadora del propi futur. 


\section{APÈNDIX DOCUMENTAL}

1388, novembre 16. Montsó.

Joan I ordena al seu enviat a Avinyó, Pere de Berga, que exposi a Climent VII la conveniència de redimir, mitjançant el pagament d'una indemnització justa, els mals usos en els dominis eclesiàstics de Catalunya.

ACA, C, reg. 1955, fol. 103 v.

Eds. Francisco MONSALVATJE, Noticias Historicas, XIII, Olot, Impr. Juan Bonet, 1906, doc. 1736, p. 167.

Item que lo dit en Pere de Berga tracte e procur ab lo Pare Sant que man e ordon ab sa bulla que, d'ací avant, alcuns hòmens propris de la Església ascripticis, solius e de reemença, los quals paguen intestia, exorquia e cogucia, dins los regnes e terras del dit senyor rey, no sien tenguts a les dites tres coses; els emperò pagant annuatim als lurs senyors ecclesiàstichs dels quals són hòmens, per rahons de lurs beneficis, certa quantitat de diners in omnem eventum, extimadora e impossadora per certes persones ecclesiàtiques, per lo dit Pare Sant açò deputadores. E de açò semblanment prometa lo dit en Pere de Berga al dit Pare Sant aquella quantitat de diners que semblant li serà a son bon arbitri.

Rex Johannes

1388, novembre, 18. Montsó.

Joan I ordena al batlle general de Catalunya que busqui a l'arxiu reial els documents probatoris de l'abolició dels mals usos al Principat.

ACA, C, reg. 1955 , fols. 105 v. -106 r.

Eds. Francisco MONSALVATJE, Noticias Históricas, XIII, doc. 1737, pp. 167-168.

Lo rey.

Batle general: Manam-vos que, vistes les presents, nos trametats traslat de totes les enfeudacions del comtat de Prades, singularment e distincta, segons que és scrit 
en lo registre. E com hajam entès que.l temps de la servitut en la qual foren estrets e obligats tots los habitands e habitadors de Cathalunya/[106 r.] la Veyla, ço és, dellà Lobregat, de pagar exorquia, intestia, cugucia e altres drets, segons les cròniques, és ja passat e açò deja ésser en lo $^{\mathrm{a}}$ nostro arxiu, manam-vos que de continent ho façats cerquar e certifficats-nos, per vostres letres, de ço que.n trobarets.

Dada a Montsó, sots nostre segell secret, a XVIII dies de novembre, en l'any de la Nativitat de Nostre Senyor M.CCC.LXXX.VIII.

Rex Johannes.

a. In interl.lineat.

1395, gener. 20, Barcelona.

Joan I sol.licita, per mitjà dels seus ambaixadors Roger de Montcada, Pere de Berga $i$ Bernat Metge, de Benet XIII que aboleixi, a canvi del pagament d'unes 10 lliures per llar $i$ d'un cens de 4 florins -2 per al Pontifex i 2 per a la Hisenda reial-la cugucia, l'eixorquia, la intestia, l'àrsia i la remença en els dominis eclesiàstics de Catalunya.

ACA, C, reg. 1968 , fol. 12 v.

Eds. Fidel FITA, Lo papa Benet XIII y los pagesos de remensa. Abolició dels mals usos intentada per lo rey d'Aragó don Joan l y la reyna dona Maria de Luna, "La Renaxensa», V-2 (Barcelona, 1875), doc. 1, p. 15. Francisco MONSALVATJE, Noticias Históricas, XIII, doc. 1738, p. 168.

Açò és memorial de les coses les quals poden ésser demanades per lo[s] ambaxadors dels senyor rey al Sant Pare, per lo sosteniment de Cerdenya e final recuperació d'aquella, mijançant l'ajuda de Déu.

Primerament lo fet dels hòmens de reemença, los quals se diu que son de $\mathrm{XV}^{\mathrm{M}}$ en $\mathrm{XX}^{\mathrm{M}}$ fochs $\mathrm{e}$ han atorgat que, si lo Sant Pare los afranqueix de cugucia, exorquia, intestia, àrcia e reemença per aquella suma de moneda que al dit Sant Pare, o a aquell $\mathrm{o}$ aquells qui per ell hi seran deputats en les parts deçà, serà vist faedor e porà ésser conegut ab los dits hòmens, convetidora en renda perpetual, a ops e profit de l'Esgleya, donaran II florins per foch al Sant Pare e II florins al senyor rey, ultra la summa dessus dita. Fa-hom compte que cascun dels dits fochs darà almenys, ultra lo IIII ${ }^{\text {ar }}$ florí, uns ab altres, $\mathrm{X}$ lliures, convertidores en renda perpetual de l'Esgleya, segons que dit és. De les quals X lliures pod ésser noresmeny tractat ab lo Papa que.l senyor rey, ultra los II florins per foch, haja alguna part convinent, per algunes provisions que l'Esgleya e los hòmens hauran ops del dit senyor, axí per seguretat de les rendes compradores con en altra manera.

Rex Johannnes.

a. Amb un signe d'abreviatura per contracció superflu. 
1402, maig, 21, València.

La reina Maria de Luna, després de declarar que els mals usos són incompatibles amb el dret de Déu i dels homes $i$ un oprobi per a Catalunya, sol.licita de Benet XIII que faculti el bisbe de Barcelona i l'abat de Santes Creus per a abolir aquests drets senyorials, en els dominis eclesiàstics de Catalunya, a canvi d'un cens permanent.

ACA, C, reg. 2350 , fols 43 r. -43 v.

Ed. Fidel FITA, Lo papa Benet XIII y los pagesos de remensa, doc. II-1, pp. 81-83.

Sanctissime pater: Vinculum caritatis unumquemque inducit ut erga ignominiose opressos, vinctos et multis plagis immaniter sauciatos manus et vires suas sublevet adiutrices. Cum itaque, pater piissime, ut vestram sanctitatem credimus non latere, in aliquibus partibus Cathalonie principatus, a longevis temporibus citra, fuerit atque sit quedam prava et detestebilis consuetudo aut servitus, in vulgari cathalano diversis vocabulis nominata, videlicet, cugucia, exorquia, intestia et arcina, reemença pendre e mal tractar, quibus plures rustici et villani ac alii homines in diversis villis, locis, eremis et inerimis dicti principatus degentes seu populati subiacent et quamplurimum affliguntur per dominates eisdem", tam ecclesiasticos quam sculares. Quequidem detestabilis servitus et prava consuetudo hos tristes et nefandos parit effectus, scilicet, quod, si uxor alicuius dicte servituti submissi adulterium duxerit comittendum, aut aliquis ex predictis decesserit nulla prole relicta ex sua uxore, aut intestatus obierit, vel eius mansus seu domus fuerit incendio concrematus, dominans seu domina[n]tes ${ }^{\mathrm{b}}$ rusticis ipsis ${ }^{\mathrm{d}}$ proinde certam partem bonorum illorum ipso facto adquirunt, contra ius divinum pariter et humanum, cum afflicto innocenti non sit addenda afflicio. Reemença vero pendre e mal tractar istam pravam condicionem important quod dominates ${ }^{e}$ ipsis $^{\prime}$ rusticis ${ }^{h}$ seu hominibus predictis ${ }^{\text {h }}$ possunt ipsos, nulla causa vel culpa preeunte, capere et in carcere mittere ipsosque ibidem detinere et maletractare, ad libitum, ommni remedio appellacionis seu recursus ad presidem seu maiorem totaliter intercluso, neque filii' eorum ad sacros ordines promoveri, matrimonium contrahere, nec ipsos mansos aut domos eorum exire possunt, causa alibi habitandi, donec primitus se redimerint a dominantibus eis', in tantum quod sunt peioris, deterioris et vilioris status et conditionis quam ceteri mundi homines iugo servitutis oppressi. Hocque, pater sanctissime, sit, apud Deum et homines, quoddam singulare, detestabile et execrabili mostruosum, deturpans et inficiens nedum subiectos ordinibus et passionis supradictis; verum etiam quod ammoda maculans patria istam et degentes in ea, sitque aliis mundi nacionibus materia illudendi seu in neglectum habendi nacionem cathalanorum; tendat necminus contra naturalem iusticiam et hominum libertate, quam Deus, ab initio, plantavit cuilibet humano subiecto. Supplicamus ab intimis clementie vestre, cui proprie competit talia extirpare, quatenus dignemini, super predictis, infrascriptam adhibere medelam, qua sanari poterit de facili ipse morbus. 
Constat etenim, pater sanctissime, et contigit multociens quod prelati et persone ecclesiastice, nobiles, barones, milites et alie persone generose, cives et ${ }^{k}$ seculares, tenentes dictos homines dicte servitutis sub iugo dictos rusticos et alios villanos supradictos ab ipso detestabili iugo liberos faciunt isto modo, videlicet, quod, facta primitus legitima extimacione et adveracione de valore et utilitate servitutum ipsarum, precium seu valorem ipsius convertunt in annuos redditus atque census percipiendos singulis annis perpetuo, per dominantes predictos', super ipsis rusticis et villanis, mansis, domibus et omnibus eorumdem; et insuper remanent ipsi rustici ${ }^{m}$ adhuc homines proprii et solidi eorumdem. Ex ${ }^{n}$ his enim que petimus, beatissime pater ${ }^{\circ}$, duo bona sequntur: libertas et immunitas tam detestabilis servitus et dictorum dominantium ${ }^{p}$ uberiores et continuati redditus atque fructus percipiendi annis singulis perpetuo, ut est dictum.

Dignemi itaque, pater clemens, ad exemplum Crucifixi, qui quos tenebat servitus antiquata a servitutis nexibus liberavit, vestro generali edicto seu bulla sufficienti, statuere et rite etiam ordinare ut quicumque ex dictis oppressis se redimere a nexibus dicte servitutis voluerit et abinde penitus liberare, servando ac cum effectu complendo formam et modum redempcionis et liberacionis superius et inferius posite, possunt se redimere et totaliter liberare. Et, ut predicta facilius valeant adimpleri, dignetur beatitudo ipsa vestra comittere et mandare episcopo barchinonesi et abbati monasteri Sanctarum Crucium, et utrique eorum / [43v.] in solidum plenariam potestatem conferendo, $\mathrm{et}^{\mathrm{q}}$ providere quod, per se et substitutos ac subdelegatos eorum, possunt, omni appellacione remota, dictas pestiferas et reprobatas servitutes, infrascriptum modum, redimere et totaliter extirpare, videlicet, quod vero precio extiment seu aprecient servitutes predictas, ipsarumque precium seu extimacionem convertant seu converti faciant, super ipsis hominibus et bonis eorum, in perpettuos redditus sive census annuatim solvendos per dictos vassallos personis ${ }^{r}$ ecclesiasticis aut eorum dignitatibus', officis seu beneficiis et aliis personis' laycis, ut tucius et firmius fieri poterit, ad comodum et augmentum dominatium predictorum", ipsis tamen vassallis remanentibus hominibus propriis et subditis ipsorum" et beneficiorum suorum, eo modo quo sunt ceteri homines et vassalli dicti principatus Cathalonie dictis servitutibus et malis usibus non subiecti, ac solventibus decimas, primicias, census et alios redditus sive fructus per ipsos dari solitos seu prestari eis dominantibus ${ }^{*}$ supradictis. Et super hoc, pater beatissime, dignetur vestra sanctitas concedere bullas seu litteras plena auctoritate vigentes et sufficientes, cum clausulis opportunis, prout facti qualitas postulat et requirit. Et hoc quippe, pater santissime, opus pium in dictos homines facietis, iuraque ecclesiastica et aliorum augmentabitis et crescetis, nacionem cathalanorum revelabitis ab ignominiosis opprobriis; unde nos erimus semper ad vestra obsequia et beneplacita promptiores.

Almam personam vestram dignetur conservare incolumen Ecclesie sue sancte regimini longeve ac feliciter opifex summum rerum.

Datum in civitate Valencie, sub nostro sigillo secreto, XXI die madii, anno a Nativiate Domini M CCCC II ${ }^{\circ}$.

La Reyna.

a. dominantes eisdem interl lineat, damunt dominos eorumdem ratllat. $b$. dominans seu domi- 
nantes interl lineat, damunt dominus seu domini ratllat. c. Escriu rusticorum $i$ corregeix sobreposant is a orum. $d$. Escriu ipsorum $i$ corregeix sobreposant is a orum. e. dominantes interl lineat, damunt domini ratllat.f. Escriu ipsorum $i$ corretgeix sobreposant is a orum. $g$. Escriu rusticorum $i$ corretgeix sobreposant is $a$ orum. b. Escriu predictorum $i$ corretgeix sobrepossant is a orum. $i$. Segueix autem ratllat. $j$. Segueix eorumdem ratllat. $k$. Segueix seg ratllat. l. dominates predictos interl lineat, damunt ipsos dominos ratllat. $m$. Segueix suorum ratllat. $n$. Segueix quibus pater beatissime ratllat. o. Des de his emi fins a beatissime pater interl. lineat. $p$. dominatium interl lineat. q. et interlinat. $r$. Segueix suis dominis ratllat. s. dignitatibus interl-lineat, damunt degeticibus ratllat. $t$. personis interl-lineat, damunt dominis ratllat. $u$. dominatium predictorum interl. lineat, damunt dominorum predictorum ratllat. $v$. Segueix dominorum ratllat. $x$. eis dominatibus interl-lineat, damunt eorum dominis ratllat.

1427 , febrer, 15. València.

Alfons el Magnànim ordena a Ferrer de Comelles, ciutadà de Girona, a Lluis de Gualbes, a Blanca, la seva esposa, i a Joana, vidua de Joan Sabrià, ciutadà de Barcelona, que s'adbereixin a la moràtoria de pensions que els altres censalistes de la Vall d'Hostoles han concedit als habitants de l'esmentada circumscripció, per tal de no accentuar la seva misèria i ajudarlos a sortir de l'aguda crisi en què es troben sumits.

ACA, C, reg. 2789, fol. 20 v.

N'Alfonso, per la gràcia de Déu, etcètera: Al feel nostre en Fferrer de Comelles, ciutadà de la ciutat de Gerona; salut e gràcia.

Be crehem no ignorets que la major partida e quaix tots los crehadors qui han e reben censals sobre la universitat e singulars de la Vall de Hostoles, dins la vagueria de Girona situada, sabents e vehents que los de la dita vall'b axí per mortedats com per sterilitats de lurs collites e splets, són pervenguts a tanta inòpia, depopulació e destrucció de lurs persones e bens que no hajen ne han possibilitat de pagar als dits creedors les pensions de lurs censals e altres càrrechs neccessaris, per què la dita vall no vinguès a total desolació e perdició, han concordats e fets certs capítols ab los síndics e prohòmens de la dita vall, los quals nos ${ }^{c}$ havem fets madurament e digesta regonéxer en nostre consell e aquells havem loats ${ }^{d}$, fermats e approvats, e de nou confirmats, aposant'hi nostra auctoritat e decret, per restauració de la dita vall, e vos havets recusat fermar, segons som informats, en los dits capítols. E com sia cosa rahonable que vos, qui havets vostres censals sobre aquella, donets, per vostre profit, tot bon expedient que la dita vall no.s despoble ni.s perda, ans per observància $e$ execució dels dits capítols puxa respirar e encara descarragar-se del insoportable càrrech que ara de presente ha, vos pregam axí affectuosament com podem que, per descarragar la dita vall, universitat e singulars d'aquella e posar en bon partit los dits vostres censals, e per contemplació nostra, vos vullats aderir als altres creedors de la dita vall e fermar los dits capítols e concòrdia sobre los pagaments e quitaments dels dits censals fets, segons dit es; pregant' e encarragant-vos que de vostra intenció sobre acò prestament [hajam] vostra resposta. 
Dada en València, sots nostre segel secret, a XV dies de ffebrer en ${ }^{8}$ l'any de la Nativitat de Nostre Senyor M CCCC XXVII.

Rex Alfonsus.

Ffuerunt expedite due alie littere similes, sub infrascripto mandato et subsimili data et signatura, directe infrascriptis:

Als feells nostres en Luis de Gualbes e na Blancha, muller sua, e a cascum d'ells; salut etcetera.

A la feel nostra na Johanna, muller den Johan Sabrià, quondam, ciutadà de Barchinona; salut etcetera.

Dominus rex mandavit michi, Ffrancischo Darinyo, et vidit eam baiulus Cathalonie generalis.

a. de la interliniat.b. vall interliniat, damunt vila ratllat.c. nos inteliniat, damunt nosaltres ratllat. d. loats inteliniat. e. segueix haje ratllat. $f$. segueix vos ratllat. $g$. en inteliniat, damunt del ratllat.

\section{RÉSUMÉ}

La Peste Noire contribua à accentuer la tension social déjà existante en Pays Catalan. La subite diminution démographique y modifie la relation de force qui existait et permet à certains secteurs de la paysannerie d'exiger des propiétaires fonciers une réduction des prestations. Les seigneurs, une fois surmontée la perplexité dans laquelle les avait plongé le changement de conjoncture, essaient de compenser, par de nouvelles exigences auprès des cultivateurs des possessions, les concessions qu'ils durent s'imposer au moment de la phase culminante de la crise. C'est alors, pendant le troisième quart du XIV ${ }^{\text {eme }}$ siècle, quand les mauvais usages se fusionnent avec la rançon et deviennent les signes d'identité de la condition servile. L'oppósition paysanne contre la pression seigneuriale devient, d'un mouvement spontané et inorganisé qu'il était, un front de résistance coordonnée.

La montée de la tension sociale à la campagne et la nécessité d'affirmer son autorité devant les feudataires, incitent la Monarchie à intervenir dans le conflit. Les Conseillers de Joan Ir et de Martí l'Humà tentent d'utiliser l'énergie des paysans pour refaire l'autorité et le patrimoine du souverain, bien mal menés à cause des difficultés économiques passées et récentes. A partir de 1400, la Couronne transfere sur les communautés campagnardes les coûts de la récupération des juridictions locales qui, sous la pression de déficits budgétaires répétés s'étaient vues obligées de mettre en gage leurs richesses ou de vendre à des membres de l'aristocratie. La redevance se répartira, dans chaque ville ou village, entre tous les habitants, en accord avec leurs patrimoines respectifs.

L initiative de la cour, bien accueillie par les petits propiétaires et les exploitants aisés, n'éveilla guère d'enthousiasme parmi les paysans pauvres, plus intéressés à se libérer du paiement de la rançon et des droits de servage que d'entrer dans la juridiction royale. Les seigneurs opposèrent une résistance ferme à la mesure qui tendait à les priver d'une importante source de revenus et d'un moyen efficace 
d'influence politique. Le processus de rançons juridictionnelles augmenta, ce qui accrut la tension sociale à la campagne, du fait de l'appauvrissement d'un important secteur de la paysannerie, et aiguillonna l'agressivité entre les puissants.

En l'espace de deux ans, 1427 et 1428, une calamité naturelle secoua la société catalane déjà hargneuse: une série de tremblements de terre destructifs à la Garrotxa, la Selva et les contrées avoisinantes font sentir d'une façon plus aiguë la diminution démographique, font empirer la crise économique et les affrontements d'intérêts. La hâte des affectés à reconquérir la normalité est imputable tant à l'importance des dégâts comme au manque d'économies, de consensus social et d'une vision encourageante du propre futur.

\section{SUMMARY}

Black Death contributes to increase the social tension already existing in Catalan counties. The sudden demographic decrease modifies the existing strength relation and allows some sectors of the peasantry to require a reduction of landlords'benefits. Once the landlords overcome the perplexity in which a change in the conjuncture had thrown them, they try to compensate the concessions they had been obliged to make during the crisis, through new demands to the farmers. It is at that very moment, during the third quarter of the XIV ${ }^{\text {th }}$ century that bad customs merge with personal redemption and become one of the signs of identity of the servile condition. Peasantry opposition against the seigniorial pressure evolutes from a spontaneous and unorganised movement towards a coordinated resistance front.

The increase of social tension in rural areas and the need to affirm her authority in front of the tax contributors, prompted the Monarchy to intervene in the conflict. Joan I"'s and Martí l'Humà's advisers tried to use the farmers'energy to recreate the king's authority and patrimony, mishandled by the passed and recent economic difficulties. Since 1400, the Crown transfers to the country communities the costs of the recovery of local jurisdictions that, under the pressure of the repeated budget deficits, she had been obliged to sell her wealth or to pawn it at members of the aristocracy. The tax was to be shared out, in all villages and towns, between all the inhabitants according to their respective patrimony.

The initiative of the Crown, well accepted by small owners and well-off smallholders, did not awaken much enthusiasm amid poor farmers, more interested to free themselves from the payment of redemption and of serfdom rights than to enter under royal jurisdiction. The landlords opposed a strong resistance to the measure that tended the deprive them of an important source of income and of an efficient political instrument. The process of jurisdictional redemptions augmented, which increased the social tension in country areas, due to the impoverishment of an important group of the peasantry, and spurred the aggressiveness between the powerful.

In the space of two years, 1427 and 1428, a natural calamity shake up the already belligerent Catalan society: a series of destructive earth quakes in the Garrotxa, La Selva and the neighbouring areas. This fact underlined even more the 
demographic decrease, made the economic crisis more profound and worsened interests confrontations. The anxiety and impatience of the affected to return to normality is imputable both to the importance of the damages and to the lack of economic and social consensus and of an ecouraging vision of their own future. 